ISSN: 0213-2060

DOI: https://doi.org/10.14201/shhme392175201

\title{
LA CONTESTACIÓN A LOS PRÓCERES. PUGNA DE FACCIONES Y DESÓRDENES EN VALENCIA (1376-1478)*
}

\author{
The Reproach of the Eminence. Fight of Factions and Dissorders \\ in the City of Valencia (1376-1478)
}

\author{
Rafael NARBONA VIZCAÍNO \\ Departament d'Història Medieval. Facultat de Geografia i Història. Universitat de València. Avda. Blasco \\ Ibánez, n.o 28, 70, València. C. e.: Rafael.Narbona@uv.es. ORCID: https://orcid.org/0000-0002-9298-0530 \\ RESEARCH ID: R-8539-2018
}

Recibido: 2020-07-20

Revisado: 2020-10-16

Aceptado: 2020-10-19

RESUMEN: La intermitencia de los ataques verbales y escritos contra las decisiones de gobierno de la ciudad de Valencia a lo largo de un siglo se inscriben en una dinámica absorbente, liderada por partidos rivales de la oligarquía, capaces éstos de asumir reivindicaciones grupales ajenas y de arrastrar a parte de los ciudadanos y de los menestrales bajo fórmulas clientelares. Las circunstancias concretas de las protestas superaron los cauces institucionales previstos en una asamblea municipal renovada anualmente y con amplia representación social, la cual se demostró más como plataforma para la adhesión de los vecinos respecto a los líderes de la sociedad política y menos como órgano de discusión por conseguir o mantener la hegemonía.

Palabras clave: Gobierno ciudadano; lucha de facciones; conflictividad política; patriciado urbano.

ABSTRACT: The intermittence of verbal and written attacks against the government decisions of the city of Valencia, throughout a century, are part of a absorbing dynamic, led by rival parties of the oligarchy, capable of assuming foreign group demands and dragging part of citizens and craftsmen through patronage formulas. The specific circumstances of the protests exceeded institutional channels, foreseen in a municipal assembly, that was renewed

* Este trabajo es resultado de los proyectos de investigación: ¿Crecimiento sin desarrollo? Distribución de la riqueza, movilidad social y acción politica en la Europa mediterránea (siglos XIII-Xv), del Ministerio de Ciencia, Innovación y Universidades del Gobierno de Espańa, PGC2018-099275-B; y Desigualdad económica y movilidad social en la Europa medieval (siglos XIII-XVI), de la Generalitat Valenciana, Prometeu 2019/072. 
annually and that welcomed a broad social representation, which was proved more as a platform to get the adhesion of neighbours with respect to the leaders of political society and less as a discussion body to achieve or maintain hegemony.

Keywords: Citizen government; factional struggle; political conflict; urban patricians.

SUMARIO: 0 Introducción. 1 Doctrina política y estructura gubernativa. 2 Mecánica política y rivalidades. 3 En la lucha de bandos. 4 Estabilidad y nueva contestación. 5 Contra las minorías. 6 Conclusiones: conflicto y vida pública. 7 Referencias bibliográficas.

\section{INTRODUCCIÓN}

La protesta y la reivindicación han sido consideradas testimonios fundamentales de la conflictividad social. Tanto sus protagonistas como los instrumentos de comunicación política empleados resultaron determinantes para expresar una opinión contraria a los discursos oficiales del bien, de la paz y de la cosa pública, recursos muy queridos en la más clásica retórica del poder urbano en las sociedades de Antiguo Régimen. Sin embargo, la cíclica contestación a estos discursos puso en entredicho los valores inherentes al buen gobierno y también la honorabilidad de los más destacados próceres de la comunidad, a través de la propagación de mensajes subversivos, orales o escritos. Esta rotunda expresividad no puede considerarse ni desconcertante ni excepcional, sino que, al contrario, su reiteración constituyó un elemento clave para la difusión de una crítica recalcitrante al orden establecido, independientemente de los heterogéneos elementos desencadenantes y circunstanciales. La difusión de este tipo de mensajes por grupos minoritarios pretendía conseguir la movilización de colectivos que, convenientemente ampliados, habrían de activar una amplia contestación ante las más diversas situaciones. Y en no pocas ocasiones la ausencia propiamente dicha de idearios programáticos de inspiración compleja se suplía con la popularización del descrédito de los líderes institucionales del momento y, con ello, esas acciones de contundente rechazo mantuvieron viva la resistencia ejercida por los opositores contra aquellos que disfrutaban de los resortes del poder ${ }^{1}$.

1 Los escritos de protesta y las voces anónimas constituyen una constante en las sociedades alfabetizadas. Por doquier se hallan mensajes denigrantes que atentaban contra el honor personal, invocando adulterios o calificando de forma peyorativa las relaciones de pareja: Petrucci, Armando. Scrittura e popolo nella Roma barroca, 1585-1721. Roma: Edizioni Quasar-Comune di Roma, 1982, pp. 24-25; Gimeno, Francisco y Escartí, Vicent Josep. «El testimonio cronístico del uso de la escritura popular-escritura criminal en la Valencia del siglo XviI». Alfabetismo y Cultura Escrita, 1988, vol. 1, pp. 23-28; Terol, Vicent. "Escriptures infamants valencianes. A propósit d'un cartell del segle Xvinı». En Gimeno, Francisco y Mandingorra, M. a Luz (coords.). Los muros tienen la palabra: materiales para la historia de los graffiti, Valencia: Universidad de Valencia, 1997, pp. 11-26; Gimeno, Francisco. «Défense d'afficher: cuando escribir es transgredir». En Idem, pp. 11-26; Bouza, Fernando. Corre manuscrito. Una historia cultural del Siglo de Oro. Madrid: Marcial Pons, 2001, pp. 109-125; y Castillo Gómez, Antonio. Entre la pluma y la pared. Una historia social de la escritura en los Siglos de Oro. Madrid: Akal, 2006, pp. 203-224. Esos insultos o difamaciones tenían implícito un componente político cuando se dirigían a los ediles o a los más relevantes personajes locales, según se comprueba cuando se analizan casos concretos: Oliva Ferrer, Hipólito Rafael. «Espacios de comunicación en el mundo rural a 
No se han hallado en esta investigación los suficientes indicios para asumir la existencia de una genuina «voz del pueblo» en estas descarnadas expresiones, ni en los tópicos argumentados sobre los deseos de libertad, de lucha contra la tiranía, de denuncia de la corrupción o en las aspiraciones de justicia, pues estos pretextos tan habituales en la manifestación de los descontentos estuvieron al mismo tiempo presentes en la misma justificación de la represión. En la mayor parte de los casos la contestación se dirigía contra aquellos conciudadanos que disfrutaban del poder, mientras las críticas trataban de defender unos intereses divergentes, pues difícilmente los gobiernos municipales podían aceptar los pluralismos políticos, dado que las ambiciones de grupo marcaban las relaciones sociales y las diferencias de clase quedaban diluidas bajo un perenne bipartidismo de carácter vertical, liderado por familias y por personajes de reconocido prestigio, bien arraigados patrimonialmente en la ciudad ${ }^{2}$.

Mientras tanto los pregones municipales denunciaban los intentos de desestabilización respecto a una situación mantenida y deseada, calificándolos como complots, como atentados contra el bien común y contra la paz pública de malintencionados destructores la comunidad, es decir, como acciones perversas protagonizadas de los enemigos de las libertades. Por el contrario, los contestatarios deseaban cambiar el orden de las cosas y las inquebrantables hegemonías ciudadanas, señalando y exagerando las situaciones de desgobierno. Puede observarse pues una doble y perseverante operación de propaganda, por un lado, institucional y, por otra, clandestina, cuando ambas intentaban mutuamente desacreditarse. Pese a la reaparición de las protestas tampoco se detecta en ellas una voluntad expresa de cambiar el sistema político sino tan solo la de sustituir a los

fines de la Edad Media: la escritura como contrapeso del poder». Medievalismo, 2006, vol. 16, pp. 96-112. También, del mismo autor, «Sobre la politización ordinaria de la gente común a fines de la Edad Media». En López Ojeda, Esther (coord.). Una nueva visión de la Edad Media: legado y renovación. XXV Semana de Estudios Medievales. Logroño: Instituto de Estudios Riojanos, 2016, pp. 259-260. Respecto a la posible independencia, o no, de la actitud política popular y de la gestión política de la enemistad, con toda su carga cáustica: Heers, Jacques. Partiti e vita politica nell'Occidente medievale. Milán: Arnolfo Mondadori editore, 1983, pp. 21-59; y Lantschner, Patrick. The Logic of Political Conflict in Medieval Cities: Italy and the Southern Low Countries, 1370-1440. Oxford: Oxford University Press, 2015, quien insiste en las múltiples formas del conflicto político, de los discursos, de las prácticas y de los grupos de acción que, asociados, permitían la absorción de las reivindicaciones o protestas, así como la transformación constante de las coaliciones políticas, a pesar de la existencia de una génesis diferencial de la movilización y de los propios protagonistas, la cual, a la postre, solía culminar con su asunción por parte de los líderes naturales de la sociedad política medieval, e inserta en una causa u opción colectiva con aspiraciones de ser general en el seno de la comunidad urbana.

2 Los ejemplos que proporciona la historiografía pueden ser innumerables: Bertelli, Sergio. Il potere oligarchico nello stato-città medievale. Florencia: La Nuova Italia Editrize, 1978, pp. 61-65; Barel, Yves. La ciudad medieval. Sistema social-sistema urbano. Madrid: Instituto de Estudios de la Administración Local, 1981, pp. 120-142; Heers, Jaques. L'esilio, la vita politica e la società nel Medioevo. Nápoles: Liguore editore, 1997, pp. 11-15; Petralia, Giuseppe. "Conclusioni». En Balbi, Giovanna Petti y Vitolo, Giovanni. Linguaggi e pratiche del potere. Genova e il Regno de Napoli tra Medioevo ed Età moderna. Salerno: Laveglia editore, 2007, pp. 377-388; Asenjo, María y Zorzi, Andrea. «Conflicto y discordia en las ciudades bajomedievales. Italia y reinos hispánicos». Hispania, 2015, vol. LXXV, n. ${ }^{\circ}$ 250, pp. 323-330; y Monsalvo Antón, José M. “El conflicto nobleza frente a monarquía en el contexto de las transformaciones del estado en la Castilla Trastámara. Reflexiones críticas». En Jara Fuente, José Antonio (coord.). Discurso politico y relaciones de poder: ciudad, nobleza y monarquía en la Baja Edad Media. Madrid: Dykinson, 2017, pp. 176-179. 
RAFAEL NARBONA VIZCAÍNO

LA CONTESTACIÓN A LOS PRÓCERES.

PUGNA DE FACCIONES Y DESÓRDENES EN VALENCIA (1376-1478)

responsables del mal gobierno, aunque en ocasiones se encontraron chivos expiatorios que sufrieron la transformación de los descontentos en disturbios de grandes proporciones.

En el caso de la ciudad de Valencia habrá que esperar a la Germanía (1519-1523) para poder escuchar la voz propia e individualizada de abajo, de artesanos, menestrales y pueblo ${ }^{3}$. La denominada "politización ordinaria de la gente corriente» se ha documentado en los casos más abajo referidos, pero siempre con estrechas relaciones respecto a la oligarquía, cuando quedaba integrada en las clientelas de las elites y sin apenas capacidad de distinguirse de los intereses patricios, siempre dispuestos éstos a asumir aquellas reivindicaciones para ensanchar la base social de su propio liderazgo. La no exclusión de los oficios de la asamblea municipal, de su numerosa y reglada representación en las ciudades de la Corona de Aragón, facilitaba la comunicación entre mayores y menores hasta absorber las problemáticas inferiores. La cultura política popular, incluso presentándose crítica, terminaba confluyendo con la oposición que ejercían las elites desplazadas de la órbita del poder local, en un medio urbano donde la lucha por el poder constituía la más sólida razón de existencia de las facciones de las elites, enfrentadas de continuo por el control de la vida pública. Todos los testimonios documentales reseńados inducen a pensar que las protestas populares en Valencia acabaron absorbidas en las causas de los mayores, incluso cuando engendraron pogromos. Las circunstancias institucionales y el juego político lo incentivaban.

\section{DOCTRINA POLÍTICA Y ESTRUCTURA GUBERNATIVA}

Ha sido muy bien asumida por la historiografía la idea de que el franciscanismo bajomedieval alimentó con su pensamiento a la clase dirigente de las instituciones ciudadanas, constituyendo un caso paradigmático en sí mismo el ejemplo que proporciona la obra y la biografía de Francesc Eiximenis ${ }^{4}$. En 1382 el fraile, de origen gerundense, se domiciliaba en Valencia invitado a residir por sus ediles. Entonces ya había iniciado la redacción de Lo Crestià, una suma teológica de carácter enciclopédico planificada en trece libros, que demostraba su maestría mediante la compilación del saber cristiano. Eiximenis residiría en la ciudad del Turia durante más de veinticinco años consecutivos

3 Un importante y contrastado conjunto de reflexiones sobre la subordinación de los grupos subalternos en la contestación política se encuentra en Oliva Herrer, Hipólito Rafael et al. (eds.). La comunidad medieval como esfera pública. Sevilla: Universidad de Sevilla, 2014. Las circunstancias de las ciudades castellanas desde mediados del siglo xv oponían a la comunidad frente a un concejo constituido por regidores vitalicios o perpetuos, donde a lo sumo tuvieron cabida los procuradores del común, circunstancia general que contrasta con la antigua presencia de los grupos populares en los consells municipales de la Corona de Aragón y la fluidez de los vínculos entre las elites y el artesanado urbanos, desmovilizándose por este camino la mayor parte de las cualquier iniciativas políticas individualizadas de los grupos inferiores.

4 Maravall, José Antonio. «Franciscanismo, burguesía y mentalidad precapitalista: la obra de Eiximenis». En VIII Congreso de Historia de la Corona de Aragón. Valencia: Sucesor de Vives Mora, 1969, pp. 285306; y Evangelisti, Paolo. I franciscani e la costruzioni di uno Stato. Linguaggi politici, valori identitari, progetti di governo in area catalo-aragonese. Padua: Editrici Franciscane, 2006, pp. 13-20. 
hasta que poco antes de morir, a finales de 1408, se trasladó a Elna para tomar posesión de la mitra episcopal. Ese espacio temporal y ese ámbito urbano marcaron el proceso de naturalización y de madurez sapiencial de un autor que elaboraría el Regiment de la Cosa Pública, un texto relativamente breve con fines pastorales, dedicado a sus anfitriones, que más tarde incorporó al duodécimo libro de su voluminoso Crestia ${ }^{5}$. En el proemio del Regiment, Eiximenis se dirigió a los ediles valencianos con la idea de proporcionarles doctrina y valores cívicos para el gobierno de la ciudad y del pueblo. Los jurados recibieron con agrado aquella dedicatoria que elogiaba sus quehaceres y decidieron conservar aquel tratado en la sala de la escribanía de la Casa de la Ciudad, encadenado sobre su mesa, para inspirarse con su consulta a la hora de elaborar ordenanzas y de dar solución armónica en los conflictos. La doctrina de Eiximenis proponía la clásica estructura orgánica y cohesionada para glosar la sociedad urbana con tres cuerpos articulados: mayor con caballeros y ciudadanos honrados, mediano con los ciudadanos, y menor con los menestrales u oficios mecánicos. Al mismo tiempo, encumbraba con alabanzas a los mercaderes, despreciaba a los campesinos por su innata rusticidad y obligaba a los próceres urbanos a controlar y reprimir a una población laboral que consideraba emigrada, levantisca y peligrosa ${ }^{6}$.

Con este esquema trifuncional convenientemente adaptado a las realidades políticas y sociales de la ciudad que lo acogía, el fraile ensalzaba las competencias de gobierno de los ciudadanos, mientras que olvidaba por completo la muy numerosa representación de los oficios en la misma asamblea de gobierno municipal. De hecho, desde 1371, la designación de los titulares de los escańos reservados a los oficios en el consell municipal había pasado a ser competencia de los jurados, quienes también comenzaron a designar a los consejeros que hasta entonces delegaban las parroquias ciudadanas, en claro perjuicio de las propuestas elaboradas por los oficios artesanales o por las mismas vecindades parroquiales. La pretendida circularidad de las relaciones de poder local quedaba completada entonces, porque desde 1283 esos mismos consejeros ciudadanos de las parroquias habían propuesto a los aspirantes en el sorteo de los cargos de jurados para la siguiente anualidad, y así siguió siendo hasta el principio del reinado de Alfonso el Magnánimo, cuando los posibles candidatos quedaron filtrados mediante un nuevo procedimiento controlado por el racional ${ }^{7}$. Mientras tanto los menestrales siempre fueron excluidos de ese trascendental menester. Es decir, desde 1371 los consejeros de los oficios perdieron para siempre el estrecho margen que habían disfrutado respecto a sus competencias pp. XV-XLIV.

Renedo, Xavier. «Introducció» del Dotzè llibre del Crestià, I, 1. Girona: Universitat de Girona, 2005,

6 Webster, Jill. La societat catalana al segle XIV. Barcelona: Edicions 62, 1980; Narbona Vizcaíno, Rafael. «La idiosincrasia de las sociedades urbanas en la Corona de Aragón. Ideales, realidades políticas y representación social (siglos XIII-Xv)». En El poder a l'Edat Mitjana. Lleida: Pagès Editor, 2004, pp. 303-310.

7 La introducción del sistema de la ceda o lista de candidatos idóneos para participar en las elecciones de jurados coincide con el inicio de la política de concesión de préstamos a Alfonso el Magnánimo, circunstancia que permitía a la oligarquía el control de los aspirantes a las magistraturas y, al mismo tiempo, satisfacer las exigencias financieras de la monarquía. El racional Manuel Palomar ya elaborara la lista o ceda anual en 1428: Bernabeu Borja, Sandra. La ciutat i el rei. Govern, societat i elits valencianes. Tesis doctoral. Valencia: Universitat de València, 2017, pp. 444-443. 
originales y, con ello, la élite ciudadana adquirió la capacidad absoluta para designar a los representantes de la mano menor en el senado local $^{8}$. De este modo, quedó fosilizado el desempeño de las facultades políticas entre ciudadanos y menestrales, activas y pasivas, con una clara dependencia y posibilidad de desarrollo del clientelismo de los segundos hacia los primeros para participar en la vida pública, ser electo consejero, o hacer llegar sus opiniones al gobierno municipal. Esta realidad quedaba confirmada en los preceptos de Eiximenis al glosar sus carismáticas propuestas de gobierno: las decisiones de la comunidad no debían quedar en manos de mayorías sino bajo el gobierno colegial de minorías; nada debería de hacerse por elección; y el pueblo debía ser apartado a la hora de adoptar las decisiones? .

La proyección de aquella doctrina sobre la realidad municipal se sostenía en los privilegios reales sobre los que se había asentado la autonomía ciudadana. Desde 1245 los jurados, un reducido colegio de vecinos notables, desempeńarían las competencias ejecutivas contando con un consejo de prohombres o consell en calidad de órgano de representación vecinal. Desde 1283 se perfiló con más nitidez aquella asamblea porque de forma paulatina el número de escaños, su fórmula de elección y la procedencia social de sus miembros irían aumentando con nuevos privilegios hasta constituir un numeroso senado, cuya convocatoria fue regular y necesaria para que los jurados aprobaran, legitimaran y publicitaran sus medidas de gobierno. El mismo privilegio de 1283 permitió abandonar el viejo sistema de cooptación empleado para renovar a los jurados e introducir un sistema sorteado, favoreciendo la implicación, la participación y la ampliación de los vecindarios parroquiales.

De este modo se demostraba el papel especialmente inclusivo del consejo municipal respecto a la sociedad civil, aunque bajo los inevitables parámetros de las jerarquías estamentales. Las doce parroquias participaban en la constitución de la asamblea con un número de escańos predeterminados, mientras que las corporaciones artesanales contaron con una representación creciente, que comprendía dos delegados por cada uno de ellos, con un total de 22 oficios y 44 escaños en 1364, de 25 oficios y 50 escaños en 1413 y de 44 oficios y 88 escaños en 1516. Desde 1329 se habían incorporado seis caballeros con escańos propios, lo que abrió paso a un acceso que hasta entonces les estaba vetado, con dos plazas más aumentadas entre los jurados, que en adelante serían seis, y con la alternancia anual en las magistraturas de justicia criminal, civil y mostassaf. Por otra parte, además de esta larga nómina de consejeros la relación de oficiales municipales, incluidos los subordinados, abarcaba un centenar y medio de vecinos, casi todos los cuales habían de ser renovados cada año en las vísperas de las principales festividades religiosas: Navidad, para los justicias, Pentecostés para los jurados y el consell, y san Miguel para el

8 Archivo Municipal de Valencia, Manual de consells, en adelante M.C., A-15, fol. 181-184 (1371, mayo 24). Esta novedad se mantuvo vigente durante el resto de la época foral. Nunca más los oficios nombraron a sus propios delegados para incorporarse a la gran asamblea municipal.

9 Molins de Rei, Daniel (ed.). Regiment de la cosa pública. Barcelona: Barcino, 1927, cap. XVI, pp. 100-101 y cap. XXXII, pp. 164-166. 
mostassaf, contando en todos los casos con el consiguiente y protocolario juramento de fidelidad a la monarquía y de defensa de los intereses de la ciudad ${ }^{10}$.

Es decir, el consell de tres brazos, manos o estamentos, quedaba proyectado con los seis escańos de caballeros, los cuatro de ciudadanos por cada una de las doce parroquias, y una cantidad creciente de consejeros de las corporaciones profesionales. Esta participación mancomunada otorgaba un fuerte componente colegial entre cuerpos asimétricos, cuantitativa y cualitativamente, en una multitudinaria asamblea, motivo por el que el consistorio pudiera entenderse como un espacio de participación, centrípeta y centrífuga, donde convergían los vecindarios de los distritos y los oficios corporativos, y desde donde se remitían las directrices de actuación gubernativa, con ordenanzas y pregones de obligado cumplimiento sobre múltiples materias. Cada parroquia daba cohesión a los barrios y cada oficio reunía los intereses confraternales, pero los dos colectivos estuvieron estrechamente relacionados con la acción colegial y de gobierno de los jurados a través del consell para vertebrar la vida social y económica.

No obstante, siguiendo el modelo común de las ciudades la Corona de Aragón, se percibía una participación popular completamente mediatizada, la cual permitía la reproducción de una minoritaria clase política en unos órganos de gobierno que, al mismo tiempo, daban cabida a una cuantiosa representación vecinal ${ }^{11}$. La pluralidad de magistraturas, su renovación anual y de todos los escańos del senado municipal con procedimientos más o menos sorteados, la amplitud numérica de sus participantes, el reparto de escaños entre estamentos, de los distritos urbanos y de las corporaciones de oficio, así como la fluidez de la participación vecinal en estas estructuras institucionales, seguían unos cánones similares. Y en todos ellos, pese a las apariencias, siempre se consagraba en poder de un selecto grupo de familias que formaban una endogámica oligarquía mediante el recurso a estrategias familiares, políticas, vecinales, electorales y sociológicas de muy diversa índole. Se cumplía pues el horizonte europeo de las realidades sociales del poder en el mundo urbano medieval, incontestablemente determinada por la existencia de unos patriciados de prolija descendencia, formados por familias perennizadas durante generaciones a la cabeza de las comunidades urbanas. Un patriciado rico, hacendado e imperecedero como clase dirigente, avalado por los privilegios reales y por los ordenamientos electorales, pero ratificando mediante consensos comunitarios su liderazgo al frente de los gobiernos ciudadanos.

10 Santamaría Arandez, Álvaro. «Los consells municipales de la Corona de Aragón mediado el siglo XIII: el sistema de cooptación». Anuario de Historia del Derecho Español, 1981, vol. 51, pp. 291-364; y Narbona Vizcaíno, Rafael. Valencia municipio medieval. Poder politico y luchas ciudadanas (1238-1418). Valencia: Ayuntamiento de Valencia, 1995, pp. 34-40.

11 Cateura Bennàsser, Pau. «El bipartidismo en Mallorca a comienzos del siglo XV». Boletín de la Sociedad Arqueológica Luliana, 1985, vol. 41, pp. 157-170; Guilleré, Christian. Girona al segle XIV. Barcelona: Publicaciones de l'Abadia de Montserrat, 1993, vol. 2, pp. 247-308; Barceló Crespí, María (coord.). Estudis Baleàrics. , 1988, vol. 31 dedicado a la organización municipal de los reinos de Mallorca, Valencia, Aragón y Cataluña; Batlle i Gallart, Carme et al. El Llibre de Consell de la ciutat de Barcelona. Segle XIV: les eleccions municipals. Barcelona: Institució Milà i Fontanals, 2007; Juncosa Bonet, Eduard. "Muyren los traydors! La lucha de bandos en Tarragona a fines del siglo XIV». Hispania, 2015, vol. LXXV, n. ${ }^{\circ}$ 250, pp. 441-466. 


\section{MecáNica POLÍtica y RIVALIDAdes}

La situación descrita permitía el ejercicio del poder patricio bajo la aparente participación vecinal ${ }^{12}$. Cabe preguntarse por qué el estamento menor se brindaba a asumir los nombramientos para ocupar los escaños de la asamblea cuando las decisiones quedaban lejos de sus capacidades, pero se entiende, porque desde 1371 se incorporaban a título personal y no representativo del y desde el oficio. No resulta extrańa, pues, su escasa presencia durante las sesiones ordinarias en contraste con la masiva asistencia a las sesiones de renovación de ese mismo senado, cuando se manifestaban las aspiraciones vecinales para participar en los cuadros institucionales, principio del ejercicio político que también lo era económico, con la derivada predisposición a optar al aprovechamiento de las fuentes hacendísticas (arrendamiento de impuestos, abastecimiento urbano, censales municipales, cargos subalternos, etc.).

Debe subrayarse que en el caso valenciano la mayor parte de las decisiones de gobierno se adoptaron por asentimiento o consenso, y pocas veces mediante el escrutinio de los sufragios de los consejeros. Esta constatación permite intuir que los consells fueron una plataforma de aceptación de las políticas iniciadas por los jurados, ya que ellos se reservaban en exclusiva la facultad de proponer temas y las correspondientes soluciones ejecutivas, las cuales eran asumidas por sus integrantes. Los debates fueron excepcionales, asociados a los temas más delicados en coyunturas tensas, mientras que las votaciones estuvieron relacionadas con la selección de algunos cargos, y solo en casos extraordinarios el sufragio era requerido para ratificar, refrendar o dar mayor validez la toma de decisiones de los ediles. La asamblea era el foro de exposición de los jurados y servía para publicitar las decisiones en distritos y corporaciones.

En la práctica el papel de la asamblea se reducía a proporcionar un cuerpo electoral y a la vez de elegibles para posteriores cargos municipales que se renovaban todos los años, de ahí que buena parte del colectivo de prohombres se reprodujese en el ejecutivo, en la asamblea o en las principales magistraturas. La oligarquía patricia se sostenía en el interés conjunto de la misma sociedad política, ampliada por la representación vecinal, pues la asistencia de los prohombres de la mano media y de la mano menor al senado municipal no puede desdeñarse como expresión de la voz de los barrios y de los oficios, una contribución informativa susceptible de propiciar iniciativas de los jurados. En ese sentido, sí puede entenderse el consell como estrado de expresión de la universitas, aunque la inmensa mayoría de vecinos nunca llegara a ocupar los escańos, lo que debe entenderse como un filtro permeable de integración comunitaria, capaz de consolidar unas organizaciones de proyección vertical en torno a los principales linajes. Las vecindades parroquiales, la

12 Para las villas y ciudades del reino de Valencia: Barrio Barrio, Juan Antonio. «La organización municipal en Alicante. Siglos XIV-XV». Historia Medieval. Anales de la Universidad de Alicante, 1988-89, vol. 7 pp. 137-158; del mismo autor, Gobierno municipal de Orihuela durante el reinado de Alfonso V (1416-1458). Alacant: Universitat de Alacant, 1995; Santamaría Arandez, Álvaro. El Consell de Valencia en el tránsito a la modernidad. Valencia: Generalitat Valenciana, 2000; Narbona Vizcaíno, Rafael. «Algunas reflexiones sobre la participación vecinal en las ciudades de la Corona de Aragón (ss. XII-XV)». Res Publica: revista de filosofía política, 2007, vol. 7, pp. 113-150; y Viciano Navarro, Pau. Regir la Cosa Pública. Prohoms i poder local a la vila de Castelló (segles XIV-XV). València: Publicacions Universitat de València, 2008. 
sociabilidad, la transmisión de intereses, las informaciones que circulasen de abajo hacia arriba, el reconocimiento de cierta honorabilidad a los grupos inferiores, las adhesiones incondicionales, las relaciones de producción, etc., facilitaban la fluidez de los contactos de la heterogénea sociedad urbana con los miembros de la oligarquía. Por este camino la participación vecinal en los consells favorecía la búsqueda de consensos intracomunitaros, acentuando las filiaciones de mayores y menores, y viceversa, por vías de diálogo y de comunicación política. No es difícil comprender que la presencia en los escańos de los menores fuese una vía de adhesión o de aproximación a los linajes principales. Solo en el caso de grandes rivalidades entre los linajes principales de la oligarquía podrían engendrarse desencuentros o choques entre grupos, que nunca se produjo entre jurados y consejeros, y fue en esos momentos de discordias o de violencias cuando quedaron al descubierto los estrechos vínculos entre la conflictividad urbana y el poder público.

Bajo esta estructura gubernativa y esta mecánica política podemos ratificar la circularidad entre electores y elegibles, entre jurados y consejeros de la asamblea, la cual fomentaba el clientelismo y, con ello, tanto la permeabilidad de las rivalidades entre las elites directivas entre los miembros de los oficios como de las problemáticas de éstos entre aquéllos. Son abundantes las noticias que implicaban a los menestrales en las facciones que oponían a las familias de la oligarquía. Familias, vecinos, amigos, parientes, compadres y colegas formaban un conglomerado de intereses opuesto a otro que estaba configurado socialmente de forma idéntica, y que también contaba entre sus filas a caballeros, ciudadanos y menestrales, cuando los más destacados de ellos ocupaban con regularidad los escaños del senado municipal. Se ha documentado la continua labor de tutela y de protección que ejercieron los más significados personajes de la oligarquía sobre un heterogéneo conjunto de vecinos, cuando los representaban, avalaban, o ejercían de fiadores ante los tribunales de justicia locales, una actividad que subraya los intereses directos que los más eminentes ciudadanos proyectaban sobre los grupos populares ${ }^{13}$.

Por otra parte, los numerosos conflictos entre los oficios afines podrían derivar de la aplicación de las ordenanzas fiscales, o de reglamentos impuestos sobre la producción manufacturera ${ }^{14}$. Las actas de los acuerdos del consell significan bien la continuidad de

13 Sobre la protección tutelar ejercida por algunos eminentes ciudadanos ante las actuaciones de la justicia sobre los miembros de los oficios artesanales. Narbona Vizcaíno, Rafael. "Política i ciutadania a la València de sant Vicent Ferrer». Afers. Fulls de recerca i pensament, 2018, vol. 33, n. ${ }^{\circ}$ 90-91, pp. 425-450.

14 La génesis de la conflictividad menestral ha sido analizada en varios de mis trabajos y cuenta con numerosa documentación entre los registros judiciales. A pesar de su autonomía y carácter particular se puede presumir que solo superó la consideración de simple criminalidad cuando sus puntuales problemáticas fueron asumidas por los partidos oligárquicos: «Competencia, conflicto y violencia en la manufactura cerámica valenciana del siglo XV», en Iradiel, Paulino, Navarro, Germán, Igual, David y Villanueva, Concepción (eds.). Identidades urbanas: Corona de Aragón-Italia. Redes económicas, estructuras institucionales, funciones politicas (siglos XIV-XV). Zaragoza: Prensas de la Universidad de Zaragoza, 2016, pp. 45-60; «Bandos populares en la Valencia del Trescientos. Obligaciones de reciprocidad, socorro y consejo en la sociabilidad urbana». En Monsalvo, José M. ${ }^{a}$ (ed.). Élites, conflictos y discursos politicos en las ciudades bajomedievales de la península Ibérica. Salamanca: Ediciones Universidad de Salamanca, 2019, pp. 271-294; y «Ruzafa, una comunidad rural convulsa (1395-1403)». En Del Val, M. ${ }^{a}$ Isabel, Martín Cea, Juan Carlos, y Carvajal, David (eds.). Expresiones del poder en la Edad Media. Homenaje al profesor Juan Antonio Bonachia Hernando. Valladolid: Ediciones Universidad de Valladolid, 2019, pp. 421-430. Como ejemplos puntuales caben añadir dos casos 
esas polémicas, sobre todo cuando el ambiente general estaba envuelto en la espiral de las luchas de bandos que enquistaban, por un lado, a la oligarquía y, otro, a los propios menestrales, hasta que ambos terminaban confluyendo ${ }^{15}$. Por ejemplo, solo entre 1396 y 1397, los tundidores o abaixadors y los sastres se quejaban de los perjuicios que les causaba el impuesto del tall del drap ${ }^{16}$; poco después entre alcuns dels oficis i mesters de la dita ciutat, e caps e majorals llurs, començaven entrar dissensions e altercacions d'ofici a ofici, e de persones a persones, per alcunes envejes e altres raons (de les quals) porien sortir escàndels e ocasions ${ }^{17}$; más tarde, se manifestó el conflicto entre los curtidores (assaonadors) y los zapateros per raó dels obratges de lurs oficis, lo qual contrast paria en primera faç odiós e dispost a gran divis e mal ${ }^{18}$; o la pugna entre cristianos viejos y conversos por la práctica del oficio de sastres ${ }^{19}$. Tampoco puede esconderse la rivalidad entre oficios, ni desdeñarse una abierta competencia entre ellos, a la hora de manifestar y hacer pública de forma ostentosa su rango en las solemnidades ciudadanas: los curtidores o blanquers y los zapateros se enfrentaron en $1421^{20}$; y de nuevo los mismos especialistas del cuero rivalizaron con los plateros por la prelación de la procesión del Corpus en $1432^{21}$. En consecuencia, se hace difícil pensar que estas disputas no fueran explotadas por los líderes de las facciones para ampliar su círculo de influencia y el respaldo de su particular causa.

La implicación de los sectores laborales en las rivalidades de los partidos ciudadanos adquiría netamente perfiles políticos ante la inminencia de las elecciones en este marco de intereses híbrido y simbiótico. Una fórmula reiterada de expresión del disentimiento respecto a las medidas ordenadas por la autoridad fue el recurso común a campañas anónimas y difamatorias, que pusieron en el punto de mira a los jurados o a los personajes de más calidad y relevancia. Los libros registros de los acuerdos municipales y los pregones allí copiados constatan la dureza de las medidas previstas por el municipio para poner fin a esa estrategia de oposición y de rechazo, que brotaban más y mejor en situaciones conflictivas. En una coyuntura inmediatamente anterior a una larga fase de bandos, entre 1376 y 1377 , el consell se hizo de eco de que personas de diferente estamento y condición social, ciudadanos y caballeros, circulaban por las calles durante la noche gritando e injuriando a hombres y mujeres muy significados en Valencia. Aquella anécdota no fue considerada un atentado banal a la fama y a la moral particular de los próceres de

concretos. Primero, la demanda de Guillem de Canals, notario y procurador fiscal del rey, contra Guillem Soler, acusándolo de resistencia y de heridas causadas a Bertomeu Jorbà y Domingo Munio, tejedores, veedores y lugartenientes del mostassaf, cuando quisieron inspeccionar el obrador textil del acusado, reconocer los peines viejos de su telar y la obra que allí se fabricaba: Archivo del Reino de Valencia, en adelante ARV, Justícia Criminal 39, mano 1, fol. 27 (1361, febrero 18). Y segundo, la ruptura de paz y tregua entre Gabriel Alcanyís y Martí de Sayes, ambos ropavejeros, porque el primero fue acusado por el segundo de confeccionar y vender una cota forrada, elaborada falsamente: ARV, Justícia Criminal 14, mano 11 (1422, diciembre 7).

15 Sobre la noticia de que los bandos de los linajes caballerescos de los Dieç y de los Soler arrastraban a numerosos ciudadanos: AMV, M.C., A-20 (1396, febrero 19).

16 Ibidem (1396, febrero 11).

17 Ídem, A-21 (1396, abril 17).

18 Ibídem (1397, marzo 7).

19 Ibidem (1397, marzo 1).

20 Ídem, A-27, fol. 300 (1421, mayo 10).

21 Ídem, A-30, fol. 6 (1432, junio 12). 
la ciudad, perpetrada por jóvenes noctámbulos, sino que se consideró que esta actitud afectaba a la esencia y a legitimidad misma de la autoridad y, en consecuencia, previó gravísimas penas para los anónimos difamadores ${ }^{22}$. Idéntica actitud juvenil y subversiva se reprodujo en junio de 1391, cuando los jurados prohibieron jugar a la pelota en las calles para evitar alborotos en las proximidades de la judería. Durante la noche una cabalgata festiva protagonizada por los jóvenes perjudicados recorrió las calles con gran griterío, reproduciendo con un simulacro carnavalesco la ejecución pública de azotes sobre uno de los participantes, quien montaba un asno a imitación del habitual procedimiento penal de exposición a la vergüenza pública, mientras que se anunciaba a grandes voces que aquel no podía pagar la multa prevista por trasgredir la norma. El jolgorio dio paso a gruesas palabras ante las casas de los jurados, increpándoles con injurias, en las que se calificaba a los magistrados y a sus mujeres como celosos y cornudos ${ }^{23}$.

\section{EN LA LUCHA DE BANDOS}

No se puede dudar que estos gritos nocturnos proferidos por jóvenes animosos y de alta cuna demostraban una abierta contestación al ejercicio del poder en los mismos prolegómenos de una cruenta lucha de bandos, donde participaron esos mismos protagonistas o sus familias ${ }^{24}$. Pero el tono político aumentaba considerablemente cuando se producía y se hacía público el desencuentro entre los intereses de la monarquía y los de la oligarquía dirigente, una circunstancia aprovechada de inmediato para hacer valer cualquier opción de recambio gubernativo.

En octubre de 1388 el gobierno municipal había escogido a cuatro eminentes ciudadanos para asistir a las cortes generales de la Corona convocadas por el monarca en Monzón, donde con su postura se mostraron divergentes de los intereses regios. Ante esta actitud díscola, Juan I remitió una queja a los jurados de Valencia para recriminar el

22 Moltes persones de diverses estaments e condicions, no tements Déu ne la senyoria terrenal, tota honestate vergonya apart posades, anaven de nit per la ciutat sonan, cridan, a vegades ab clares a vegades ab contrafetes veus, difaman ab vils e leges e desonestes paraules, moltes e diverses persones, axi hòmens com dones de diverses estaments e condicions, unas circunstancias que provocaban gran e destrucció de la cosa pública" y tenían prevista "pena de perdre lo cap, o de ésser negat si és hom de paratge o ciutadà honrat, e sots pena de penjar si és de qualsevol altra condició, en manera que muyren: AMV, M.C., A-17 (1376, agosto 1; y 1377, marzo 24).

23 A la semana siguiente de los hechos comparecieron mosén Joan de Bellvís, mosén Aznar Pardo de la Casta y mosén Pelegrí de Montagut, con el fin de disculpar las acciones de algunos vástagos de afamados linajes, los cuales habían sido presos por el justicia. Los caballeros suplicaron el perdón aduciendo que tanto el desconocimiento de la ordenanza como el insensato comportamiento habían llevado a aquellos jóvenes per solaç e per lascivia del jovent ... a peguejar e arlotejar. La solicitud fue escuchada, dado el ascendiente que aquellos tres personajes tenían sobre la ciudad, decidiéndose finalmente su liberación sin castigo: AMV, M.C., A-19, fol. 234-236v (1391, junio 16 y 23).

24 Pese a la presunta intranscendencia de este asunto menor los jurados transmitieron el incidente a su representante en la corte, Pere Marrades, a la sazón botellero de Juan I, con el fin de que hiciera llegar la noticia a oídos de aquel, ya que muchos caballeros habían hecho causa común con los jóvenes e insultaban abiertamente a los jurados: AMV, Lletres Missives g3-5, fol. 15-16 (1391, junio 15); Rubio Vela, Agustín. Epistolari de la València medieval. Institut de Filologia Valenciana: València-Barcelona, 1985, doc. 124, pp. 321-323. El 9 de julio se produjo el asalto y robo de la judería de Valencia. 
comportamiento de sus síndicos y, en consecuencia, aquéllos fueron sustituidos y procesados por traición. Se inició un largo proceso ante el tribunal de la gobernación y se desencadenó una profunda división de la sociedad valenciana ${ }^{25}$. Mientras se desarrollaban las sesiones del proceso, el 29 de marzo de 1390, un pañero llamado Sarrovira, quien regentaba el obrador textil de Joan Suau, uno de los acusados, difamó a los nuevos síndicos que habían sustituido a los procesados, hablando en favor de los primeros. Según consideró la autoridad municipal, sus palabras podían promover discordias y sediciones entre el pueblo, motivo por el que se previó su castigo como propagador de cizañas. Meses después, el 23 de julio de 1390, las esquinas y las paredes de la ciudad aparecieron cubiertas de carteles y de epitafios anónimos en favor de los síndicos procesados. Y el 16 de noviembre de aquel mismo ańo el consell expresó su voluntad para que fueran sometidos a tormentos judiciales y confesasen sus crímenes sin dilaciones, una actitud que motivo un alud de improperios por parte de los encausados ante el mismo tribunal, contra el síndico y los jurados porque se ponía entredicho su honorabilidad y buena fama $^{26}$. De alguna manera, aquellos acontecimientos coadyuvaron a desencadenar un malestar que propiciaría el asalto de la judería de Valencia un año después y, de hecho, a aquellos mismos personajes se les acusó de haber participado en el proyecto de sublevar al pueblo contra los jurados ${ }^{27}$. El larguísimo pleito de traición contra los primeros síndicos enviados a las cortes generales de Monzón concluiría con el acceso al trono de Martín el Humano en 1396, quien promovió un rotundo cambio en la corte real y en el gobierno municipal de Valencia. Los hasta entonces acusados fueron rehabilitados como ciudadanos honorables y se reincorporaron a la vida política local desempeñando un papel principal en los años posteriores ${ }^{28}$. Sin embargo, en 1401, la ciudad apareció de nuevo

25 El consell eligió el 3 de octubre de 1388 como emisarios a Pere Joan y a micer Bonifaci Ferrer, jurados, más Joan Suau, menor, Berenguer de Rabinats y Jaume Romeu, ciudadanos. El 23 de julio de 1389 Juan I se quejaba ante el consell de la postura contraria a los intereses regios que defendían sus síndicos. El 31 de agosto se decidía procesarlos por traición: Llop Català, Miguel. «Proceso a Bonifacio Ferrer». Escritos del Vedat, 1980, vol. 10, pp. 415-471.

26 Sobre Sarrovira: AMV, M.C., A-19 fol. 118v (1390, marzo 29). Se presumía que los epitafis, cartells $o$ titols posats en alcuns cantons o parets de la dita ciutat habían sido inspirados por los síndicos acusados de traición: Ídem, fol. 155v-156 (1390, julio 23). Sobre los insultos a los jurados y consejeros de Valencia: Ídem, fol. 180-181v (1390, noviembre 16).

27 El pleito acabó mezclándose con el proceso del asalto de la judería el 9 de julio de 1391 . Un mes después, el 5 de agosto, los jurados comunicaron al rey que el castigo del pogromo se dilataba debido a la importunitat d'alcuns magnats, per sí o per lurs parents o familiars culpables, qui en tant com ells es dilaten lo procés e desvien que.ls culpables no sien denunciats, menaçan los clamaters qui han reebut lo dampnatge si.ls notifiquen a vostre fischal, com dels dits culpables hi haja de totes condicions, és a saber, axí hòmens d'Orde de Montesa, e de mendicants, exempts, com de cavallers e hòmens de paratge, e escuders de casades com encara de ciutat. Los vínculos sociales verticales que unían a los asaltantes de la judería fueron aprovechados por los síndicos procesados y por sus partidarios para acusar a los jurados de tolerar y de participar en el asalto, al mismo tiempo que azuzaban a los menestrales contra su autoridad, per ço induexen molts del poble a desgrat e malevolença contra nosaltres: AMV, M.C., g3-5, fol. 37-37v (1391, agosto 5).

28 Berenguer de Rabinats fue consejero de la parroquia de santa Catalina y justicia criminal en 1398; Jaume Romeu, seguramente hijo homónimo del síndico procesado, gozando del nuevo estatuto de caballero, fue consejero en 1405 y jurado en 1407; Pere Joan, ejerció de consejero por santa Catalina en 1401 y fue electo jurado en 1402; Joan Suau, menor, fue designado alcaide de Chelva en 1402 y ejerció de racional entre 
empapelada de pasquines difamatorios contra las autoridades, suscritos con nombres comunes de menestrales, pero con idéntico propósito de sublevar al pueblo contra los jurados, según ellos mismos argumentaban ante el consell. En aquel momento una de las dos facciones rivales había sido expulsada de Valencia, aunque se reconocía explícitamente que sus agentes se esforzaban con distintas estrategias para volver a acceder al gobierno municipal ${ }^{29}$. En abril de 1404 cuatro notarios recababan testimonios para la investigación iniciada sobre nuevos libelos difamatorios aparecidos en Valencia ante la difusión de la noticia de que el rey y la reunión de cortes se trasladarían desde Segorbe a Valencia ${ }^{30}$.

Pese a la habitual filiación de los grupos populares hacia las causas lideradas por las élites, también se puede observar de forma ocasional una abierta adhesión popular a las iniciativas de la monarquía, sobre todo cuando ésta pretendía desacreditar, primero, y renovar, después, al grupo patricio que dominaba la ciudad. Sin duda porque los intereses mutuos eran abiertamente divergentes, y porque el sector popular descontento tampoco se encontraba bien tutelado por los ediles del momento. Martín el Humano intervino la autonomía del gobierno ciudadano para revertir el dominio del vizcondado de Chelva a su antiguo señor ante sus continuos atentados a la jurisdicción de la ciudad ${ }^{31}$. Con la excusa de paralizar la lucha de bandos. El rey despidió a los principales cuadros directivos de la ciudad en vísperas de la Navidad de $1405^{32}$. El virrey, el gobernador y el baile general se presentaron en el consell acompańados de gran número de menestrales, ordenando que además de las elecciones de justicias también se debía renovar al racional, a los abogados pensionados de la ciudad, al síndico y al notario escribano del consell, cuya designación correspondía en exclusiva a los jurados. Es decir, el 22 de diciembre de 1405 la Casa de la Ciudad se vio desbordada por la asistencia inusual de muchos artesanos que abarrotaron la amplia sala de reuniones ${ }^{33}$. Uno de los asistentes al pleno, sin ser identificado expresamente, señaló a viva voz que también debían ser despedidos los jurados.

1403 y 1405. Mientras, Bonifaci Ferrer, dejó el estado laico para profesar cartujo y encabezó la legación de Valencia ante el papa de Avińón en 1402 en calidad de prior de Porta-Coeli.

29 La mitad de los personajes que participaron en la reunión de cortes iniciada en agosto de 1401 estaban directamente implicados en las luchas de bandos, según se deriva del contraste de referencias: Muñoz Pomer, Rosa. «Las Cortes a través de la ciudad: Valencia en las Cortes de don Martín». Saitabi, 2001-2002, vol. 51-52, pp. 137-151. El grupo formado por las familias Marrades, Novals y Soler había sido expulsado de Valencia, pero s'esforcen tornar e revenir ab moltes cauteles, art, giny i maneres (per a) ésser en lo dit regiment posan e fican per portes, a palès e públich, legir libells e epitafis difamatoris, no nomenant-se aquells, mas imposantse noms d'oficis mecànichs o de llinatge de menestrals, e nomenants alcuns dels regidors per llurs propis noms per zizanyar los regidors, e pus verament concitar lo poble: AMV, M.C., A-22 (1401, març 17).

30 AMV, M.C. A-22, fol. 285v (1404, abril 11).

31 Tras la ocupación militar la baronía de Chelva quedó en manos de Valencia durante doce años, entre 1395 y 1408, hasta que por orden de Martín el Humano el gobernador la recuperó manu militari. Finalmente, el monarca la devolvió a su señor: Rubio Vela, Agustín. «El justicia de Aragón frente a la ciudad de Valencia. Un conflicto entre oligarquías territoriales, 1395-1404». Aragón en la Edad Media, 2014, vol. 25, pp. 273-322. Sobre la toma de posesión real de Chelva y el proceso iniciado el 13 de marzo de 1408 por los daños causados por el gobernador durante la ocupación, cfr. AMV, Processos, vv-12.

32 AMV, M.C., A-22, fol. 374 (1405, diciembre 22) y fol. 387-388v (1406, enero 8).

33 La sala se colmó de tanta gente que ultra los dessús qui són del consell format de la ciutat, segons ordre de furs e privilegis e provisions reyals, veng(ue)ren en aquest consell gran còpia d'hòmens d'oficis e caps de mesters, e menestrals, en tal e tant nombre, que segons mostrava experiència ocular paria que sobrepujassen lo dit consell, 
Los oficiales municipales fueron destituidos por orden real, y sustituidos mediante una lista elaborada de forma conjunta por el virrey, el gobernador y los jurados. Días después se presentó ante el consell un alguacil para comunicar que el rey le había enviado con la misión especial de acabar con los bandos en los que también estaban implicados los menestrales, ordenando un pregón en el que prohibía a los oficios que se mezclasen en las rivalidades de las élites. De este modo, se pretendía forzar que el gobierno de Valencia aceptase el intercambio de Chelva por otro dominio real, bajo la amenaza de que en caso contrario el monarca tomaría el señorío sin negociación alguna, como así ocurrió. Más tarde, en Pentecostés de 1406, fecha prevista para la elección anual de los jurados, el rey suspendió la presentación de candidaturas parroquiales proponiendo preseleccionar él mismo a quienes considerase idóneos. Por último, Martín se hizo entregar las propuestas parroquiales de jurados y de consejeros y designó sin sorteo alguno a todos los miembros del consell mediante una intervención temporal de la autonomía ciudadana que le permitió conseguir su propósito ${ }^{34}$.

\section{Estabilidad y NUEVA CONTESTACión}

Tras la guerra civil desatada durante el interregno (1410-1412), la nueva dinastía Trastámara logró pacificar las violentas rivalidades de facciones, que habían asolado Valencia desde hacía casi cuatro décadas ${ }^{35}$. Después, Alfonso el Magnánimo procuró la reforma funcional del municipio formando un gabinete de gobierno ampliado, en el que además de los jurados se integraron el síndico, el racional, el notario escribano del consell y los abogados de la ciudad, lo que tras las elecciones provocó la aparición de pasquines en contra hasta en las mismas puertas de la catedral en julio de 1418. Con esta y otras reformas el servicio al rey se convirtió en el horizonte común de la oligarquía para escalar posiciones ventajosas en la administración urbana y, con ello, la competencia entre grupos de presión adquirió un perfil dialéctico que favoreció la conjunción de intereses entre el poder ciudadano y la monarquía ${ }^{36}$. El papel principal que en adelante desempeñaría el racional, antiguo contable y auditor municipal, transformado en indefectible elemento

segons la ocupació dels banchs ordenats a seure els consellers, no per altra numerada certitud o nombre: AMV, M.C., A-22, fol. 374 (1405, diciembre 22).

34 Sobre el intento de preselección de candidatos: AMV, M.C., A-23, fol. 13v-14 (1406, mayo 25). Sobre la designación de los titulares de las magistraturas y escaños: Ídem, fol. $17 \mathrm{v}-18$ (junio 5).

35 Salvo excepciones la sentencia de Caspe fue aceptada en la Corona de Aragón. La insurgencia solo fructificó de la mano de Antón de Luna en Aragón, y de la rebelión del señorío de Bunnol en Valencia, durante junio de 1413. En Valencia se eliminó preventivamente pero el 11 de mayo de aquel mismo ańo se denunciaba que en las calles se oían canciones contrarias a Fernando: Rubio Vela, Agustín. «Urgelistas valencianos. Sobre la oposición a Fernando I de Trastámara». Anuario de Estudios Medievales, 2003, vol. 33, n. ${ }^{\circ}$ 1, pp. 191-261; y del mismo autor, «Después de Caspe. El urgelismo y las oligarquías». En Sesma Muñoz, José Ángel (coord.). La Corona de Aragón en el centro de su historia, 1208-1458. El Interregno y el Compromiso de Caspe. Zaragoza: Gobierno de Aragón-Grupo de Investigación C.E.M.A., 2012, pp. 267-268 y 282-284.

36 Sobre el deseo de apartar a personas indeseadas del gobierno y las quejas consiguientes: Ryder, Alan, Alfonso el Magnánimo, rey de Aragón, Nápoles y Sicilia. Alfons el Magnànim: València, 1998, p. 86, nota 27. Sobre la nueva situación: Bernabeu, Sandra. La ciutat i el rei, pp. 115-139. 
articulador de las relaciones políticas y financieras entre ambos, resultó fundamental. No solo gestionaría, procuraría e intervendría los recursos hacendísticos, sino que en gran medida los pondría al servicio de los proyectos monárquicos y, al mismo tiempo, asumía la responsabilidad de habilitar las candidaturas en las elecciones a jurados, mediante un proceso de acreditación de la idoneidad que introducía su visto bueno sobre los aspirantes mediante la confección de una lista o ceda. El sistema produjo unos resultados sorprendentes, porque las luchas de bandos desaparecieron de la ciudad y Valencia adquirió creciente importancia para la corona. El racional Manuel Palomar alargó su mandato entre 1428 y 1435; su inmediato sucesor, Manuel Suau, lo ejerció de forma vitalicia hasta 1455; y Guillem Çaera, su sobrino, lo continuó hasta su muerte en 1477, consolidando un largo período de estabilidad institucional ${ }^{37}$.

Pese a la hegemonía del grupo encabezado por Guillem Çaera en el municipio, la competitividad se mantuvo viva para conseguir el control de la diputación, de modo que el servicio a Juan II comenzó a chocar con los intereses de los desplazados, liderados por Lluís Cruilles, simpatizantes de la causa de Carlos de Viana y, en consecuencia, pronto se manifestó un nuevo brote de contestación ${ }^{38}$. En la noche del 27 de febrero de 1461, cuando el príncipe acababa de ser liberado de la prisión de su padre, Juan II, y continuaba reclamando sin éxito la transmisión del trono materno de Navarra y el reconocimiento de su primogenitura en la Corona, sus partidarios de Valencia, distanciados de los jurados «juanistas», volvieron a empapelarla de carteles donde se exigía que por el bien del reino toda la población estuviese armada contra los traidores y malos consejeros del rey, dada su negativa a concederle sus legítimos derechos ${ }^{39}$. Al día siguiente, se hizo constar en el consell que esos escritos parietales —abominables, odiosos y distribuidos por malvadas y perversas personas-, contenían moltes coses detestables que promoverían la conmoción del pueblo. En consecuencia, se inició una investigación para hallar a los autores, se ofreció una recompensa económica de trescientos timbres de oro para favorecer la colaboración ciudadana, e incluso se previó perdonar a cualquiera de los intervinientes si delataba a sus compañeros. El 2 de marzo se publicó el correspondiente pregón, ordenado por parte el gobernador del reino, el justicia y los jurados de Valencia para conseguir que se denunciase a quienes habían mesos, posats e affixos per les places, cantons e lochs públichs de la ciutat certs epitafis e cartells que atentaban contra el orden público y el gobierno de la ciudad y del reino ${ }^{40}$. La ordenanza parece que no obtuvo los frutos deseados, porque de nuevo cuatro meses después, el 19 de junio de 1461, volvieron a aparecer más albaranes

37 Cfr. Narbona Vizcaíno, Rafael. «Alfonso el Magnánimo, Valencia y el oficio de racional». En D’Agostino, Guido y Buffardi, Giulia (eds.). XVI Congresso Internazionale di Storia de la Corona d'Aragona. Celebrazioni Alfonsine. Nápoles: Comune di Napoli-Paparo Edizioni, 2000, vol. I, pp. 593-617.

38 Rubio Vela, Agustín. Valencia, el Príncipe de Viana y Juan II. Un patriciado ante la crisis politica de la monarquia (1460-1461). Valencia: Gráficas Papallona, 2016, pp. 24-30.

39 AMV, M.C., A-37, fol. 60v-61 (1461, febrero 28); Escartí, Vicent Josep y Borràs, Marc Jesús. "Albarans de commoure a la València del segle xv. Sobre els usos públics i criminals de l'escriptura». En Ferrando, Antoni y Hauf, Albert (eds.). Miscel.lània Joan Fuster. Estudis de Llengua i Literatura IV. Barcelona: Abadía de Montserrat, 1991, docs. I.1 y I.2, pp. 90-91; y Rubio, Agustín. Valencia, el Príncipe de Viana y Juan II, pp. 48-51; 101-103; doc. 52, pp. 173-174; y doc. 68, pp. 187.

40 Escartí y Borràs, "Albarans» doc. I.3, pp. 91-92. 
contra los regidores, donde se impulsaba al pueblo a atentar contra sus personas y bienes, circunstancia que motivó el ofrecimiento de otros mil timbres de oro de recompensa para quien o quienes llevaran a conocer a sus autores o inspiradores. De hecho, el verguero municipal exhibió una saca repleta de monedas con aquella cantidad durante los pregones que publicó durante tres jornadas consecutivas, los cuales depositó en la banca de Miquel de Vita para dar credibilidad a su entrega ${ }^{41}$. Según el testimonio de Melcior Miralles la investigación logró si no identificar al menos sí acusar a Lluís de Vesach, que según testimonio del coetáneo narrador había ejercido de jurado dos veces. No obstante, las fuentes municipales solo permiten documentar a Felipe Vesach como un destacado prócer de la ciudad que, éste sí, había ejercido antes y ejercería después diferentes magistraturas municipales ${ }^{42}$. Todos los indicios apuntan a pensar que la acusación resultó inútil, que Felipe Vesach continuó desempeñando un papel importante en los órganos de gobierno de la ciudad, y que su hijo Lluís quedó vinculado a la administración real veinte años después.

Aquellos dos incidentes de 1461 venían a significar que el equilibrio político y la paz social que había reinado en la ciudad durante décadas comenzaba a tambalearse en medio de las disputas dinásticas, como también el principio de una nueva fase de contestación política, porque no habría que esperar demasiado para que las esquinas volvieran a cubrirse de libelos y de carteles difamatorios. La siguiente oportunidad se manifestó en octubre de 1467 cuando el gobernador del reino y los ediles municipales intentaron descubrir a sus autores al considerar, otra vez, la extrema peligrosidad de los mensajes y la implícita previsión de turbaciones sociales ${ }^{43}$. Aquel año los catalanes rebeldes a Juan II sostenían los derechos al trono de Renato de Anjou, duque de Provenza, quien envió tropas al mando de su hijo, Juan de Lorena, inaugurando la última fase de la guerra civil catalana, y es posible que se generasen algunas simpatías en Valencia. No obstante, el municipio seguía dirigido por férrea voluntad del racional Guillem Çaera, quien gozaba de la plena confianza regia y estaba dotado de plenas competencias, financieras y políticas, capaces de dejar en un lugar subordinado a los jurados y al senado municipal. Nada se hacía en Valencia sin su consentimiento ${ }^{44}$.

La efervescencia política y social que se intuía con aquella propaganda clandestina contra el gobierno ciudadano surtió efecto. Dos años después, en diciembre de 1470, el mismo rey a través del gobernador del reino, del justicia criminal y de los jurados

41 Escartí y Borràs, «Albarans» doc. II.1, II.2, II.3, II.4, pp. 92-94; y Rubio, Agustín. Valencia, el Príncipe de Viana y Juan II, doc. 153, p. 279.

42 Felipe Vesach, fue jurado ciudadano en 1463, 1466, 1471 y 1482; jurado veterano y, en consecuencia, asesor de los noveles, en 1464, 1467, 1472, 1483; justicia civil en 1461; y consejero ciudadano de la parroquia de san Bartolomé en 1457, 1461, 1468, 1473 y 1478. Su hijo, Lluís Vesach, recibió en 1481 el cargo de escribano del maestre racional del reino, que Alfonso el Magnánimo había concedido a su padre: Escartí y Borràs, «Albarans» p. 84 y nota 34.

43 Se previó el perdón y otra recompensa económica de 1.500 reales, pero no conservamos testimonio de que las pesquisas obtuviesen resultados. AMV, M.C., A-38, fol. 151-151v (1467, octubre 14 y 21).

44 En Valencia, comptes, governador, justícies, jurats, conselés e tots de la dita ciutat de València no fien sinó lo que en Çahera volia, car no s'i donava hofici, ni benefici ni res de la ciutat sinó lo que en Çahera volia e ordenava: Rodrigo Lizondo, Mateu (ed.). Melcior Miralles: crònica i dietari del capellà d'Alfons el Magnànim. València: Publicacions Universitat de València, 2011, p. 457. 
publicaron un pregón con el propósito de mantener la paz ciudadana, donde se prohibía — como años atrás_ que los menestrales y "altres del poble» no se implicasen ni apoyasen las luchas de bandos que encabezaban algunos linajes de la aristocracia, de los caballeros y de los ciudadanos, bajo pena de muerte y de pérdida de todos sus bienes. El pregón estaba dirigido a tots e sengles qualsevol artistes e menestrals e altres poblats en la dita ciutat e cascun d'ells para perseguir cualquier conato de defensa, auxilio o ayuda, directa $\mathrm{o}$ indirecta, fehaciente o clandestina a aquellos magnates ${ }^{45}$. Meses atrás, a finales de julio de 1470, la ciudad de Valencia había comprado al rey el ducado de Gandía, con la villa, su término y el castillo de Bairén, una decisión que proveía de recursos monetarios a Juan II para responder a los últimos embates de la guerra civil catalana ${ }^{46}$. Desde aquella fecha hasta 1486 Valencia ejercería la jurisdicción sobre la baronía en un marco de inestabilidad alimentada por las alineaciones de un patrimonio real muy minorado, del conflicto catalán y de la creciente efervescencia contra el racional Çaera, quien se reservó hasta el final de su vida el ejercicio de la procuración y bailía del señorío ejercido por la capital.

A estas complejas circunstancias habrían de añadirse las turbulencias generales del reino ${ }^{47}$. Y también el lastre heredado de la peligrosa contestación de algunos nobles que simpatizaron con la rebeldía catalana en el decenio precedente. Si desde el verano de 1462 Valencia apoyó con firmeza a Juan II en aquel conflicto tampoco dudó en nombrar doce lugartenientes del justicia criminal, uno por parroquia, para evitar posibles alteraciones del orden público. Poco después, en octubre, la connivencia del noble Fernando de Sandoval, conde de Castro, y de su hermano Diego de Sandoval, condes de Denia y señores de Ayora y Jávea, con Enrique IV obligaron a la capital a ocupar mano armada el castillo de Denia. En el mismo sentido, también fue necesario neutralizar las aspiraciones de Joan de Cardona, señor de Ondara, Guadalest y Confrides. Y Jaume d'Aragó, señor de la baronía de Arenós, distribuyó carteles en Castelló, Borriana, Vila-real y Onda, invitando a las poblaciones a rebelarse contra Juan II y a favor de Pedro de Portugal, nuevo rey de los catalanes, atacando Bechí, Vila-real, Alcora y Lucena en el norte del reino, aunque la reacción de la capital fue inmediata y provocó la ocupación militar de su baronía ${ }^{48}$.

La campańa contra el omnímodo poder del racional Çaera alcanzó su punto álgido en la noche del 20 de marzo de 1474, cuando Valencia amaneció otra vez sembrada de pasquines en los que se llamaba al pueblo a incendiar su casa, alegando que aquel destruía los fundamentos de la ciudad y del reino. Pese a la oscura procedencia de aquellas voces el

45 AMV, M.C., A-39, fol. 153-153v (1470, noviembre 23 y diciembre 4).

46 El contrato de venta se encuentra en AMV, Notals de Jaume Eiximeno, t-2 (1470, junio 27).

47 Melcior Miralles constataba con expresivas palabras el giro experimentado en el ambiente político y la creciente inestabilidad: En lo dit any. LXX. lo senyor rey don Johan e lo senyor príncep don Ferrando an empenorat Gandia a la ciutat de València; la baronia de Corbera, a mossén Caròs; Sogorb, donada a l'infant don Anrich. En Gandia, grans bregues dels Balagués ab los Marchs; en Sogorb, los de la ciutat contra los de l'infant. Les terres e regnes se comencen a enarbolar: Déu, per sa mercé, nos done pau e salut!: Rodrigo. Melcior Miralles: crònica, p. 457.

${ }_{48}$ Bernabé, Sandra. La ciutat i el rei, pp. 487-504. Sobre la abierta sublevación de Jaume d'Aragó, cfr. Rubio Vela, Agustín. Epistolari de la València medieval II. Barcelona-València: Institut Interuniversitari de Filologia Catalana-Abadía de Montserrat, 1998, doc. 105, pp. 283-285, y Rubio, Agustín. Valencia, el Principe de Viana y Juan II, pp. 82-91. 
consell preveía la roÿna de aquesta repúblicha, el deservicio al rey y la destrucción de la cosa públich $a^{49}$. Los jurados y el lugarteniente real ofrecieron quinientos florines para quien delatase a los implicados en la distribución por lochs públics, e cantons e places de la ciutat, hon acostuma freqüentar la major part del poble de unos nephandissims cartells. El 21 de marzo se pregonó y se anunció la recompensa con carteles en esos mismos lugares. Sin embargo, no se documentan testimonios de alboroto alguno y Guillem Çaera moriría en su cama tres años después. En aquella ocasión la causa del insultante descontento parecía estar sospechosamente relacionada con la especulación y alto precio de trigo ${ }^{50}$.

\section{CONTRA LAS MINORÍAS}

La simultaneidad de las principales acciones xenófobas con la fase más dramática de las luchas de bandos había sido evidente. La coincidencia fue completa durante el asalto a la judería de Valencia el 9 de julio de 1391. Según se anotó, justo en el mes anterior, se manifestaron tensiones a través de unos jóvenes a los que se les había prohibido jugar a la pelota, lo que provocó una reacción contra los más significados próceres de la ciudad. La descripción municipal del pogromo incide en el protagonismo de otro grupo de jóvenes que cabalgando un asno y portando un pequeño estandarte iniciaron la agresión bajo la consigna de «bautismo o muerte» de los hebreos. Aquella ira xenófoba también pretendía alcanzar a los mudéjares, pues algunos de los implicados comenzaron a alborotar al día siguiente en torno a la morería con idéntico propósito, haciendo necesario la creación de una legación pacificadora ${ }^{51}$. No cabe duda que los sermones contra los judíos proporcionaron la necesaria desinhibición popular si no dotaron de cierta cobertura justificativa al ataque, pero la participación en el asalto de significados prohombres y caballeros de Valencia vuelve a inscribir esta violencia en la rivalidad de las facciones, derivada de la polémica ampliación de la judería prevista por el consell. Entre los implicados en el asalto aparecieron apellidos de renombrados caballeros, como Bordils, Siscar o Carroç, y de ciudadanos con larga experiencia como Valldaura y Carbonell. De hecho algunos de ellos, como Carbonell y Eximénez habían comenzado a animar a los artesanos para la sedición ante la posibilidad de ser $\operatorname{presos}^{52}$. Y no hubo inconveniente en asociarlos, junto

49 Melcior Miralles anotó: Diumenge a XX de marc de l'any M CCCC LXXIIII, en la nit, foren messos per molta part de la ciutat albarans dient: "poble, què sperau? Anau e meteu foch a casa d'en Çahera, e féu-ne çacrifici a Déu, car aquest és destroïdor de València e de tot lo regne!, p. 428. También AMV, M.C., A-40, fol. 91v (1474, marzo 27). Documentos publicados por Escartí y Borràs, «Albarans» doc. III.1, III.2, y III.3, pp. 94-96.

${ }_{50}$ Escartí y Borràs, «Albarans» p. 85 , nota 38.

51 AMV, M.C., A-19, fol. 251-251v (1391, agosto 1).

52 La detallada noticia del asalto: Rubio, Epistolari, doc. 103, pp. 269-270 y doc. 104, pp. 271-275. Sobre las circunstancias: Narbona Vizcaíno, Rafael. «El trienio negro: Valencia, 1389-1391. Turbulencias coetáneas al asalto de la judería de Valencia». En la España Medieval, 2012, vol. 35, pp. 179-183. El fracaso de los jurados a la hora de contener la violencia llevó al grupo antagónico, formado por los síndicos procesados por traición, a comunicar por carta al mismo rey que ellos eran más y mejores que los regidores de la ciudad, mientras los jurados hacían lo propio notificando que algunos de los apresados por el asalto eran de la part antagónica: AMV, Lletres Missives g3-5, fol. 33-34 (1391, julio 28) y fol. 35-36 (1391, julio 29). Pere de Siscar, Hug de Bordils, Lluís Carbonell y Nicolau Valldaura están documentados como partidarios del 
a otros ciudadanos y menestrales, con la facción de los síndicos procesados por traición y a la formación de una conspiración o germania con los de Alzira para culpabilizar a los jurados de Valencia ante el rey. Un año antes la presión política sobre el gobierno municipal había sido tan grande por parte del partido de los procesados que el consell aprobó la confección de un libro oficial, denominado del Bien y del Mal, para construir una damnatio memoriae que marcase para siempre a los enemigos y, al mismo tiempo, colmara de halagos a los regentes del poder y a sus partidarios ${ }^{53}$

Estas circunstancias extremas tornaron a reproducirse ocho años después, aunque con el objetivo fijado en el barrio islámico. El 16 de septiembre de 1399 una carta de los jurados dirigida al gobernador notificaba que, otra vez, un grupo de jóvenes cabalgando asnos y liderados por un pequeño estandarte se dirigieron a la morería clamando para que se diera muerte a los moros, alentados por las proclamas de un beguino que pontificaba contra unos supuestos negocios del mercader mudéjar Xupió, con los que se habría hecho fracasar la campaña marítima en el norte de África y el asedio de Bona ${ }^{54}$. En ambos casos, ante la judería y ante la morería, la agitación juvenil actuó de desencadenante para engendrar pequeńas violencias, incentivar la participación de un mayor grupo humano, y provocar o intentar provocar el ataque a las dos aljamas, pero todos los indicios apuntan a pensar que la rivalidad subyacente entre los bandos fue determinante. El ambiente no podía ser más propicio, en 1391 y en 1399, para movilizar a la población contra las dos minorías, pues los jurados de Valencia fueron culpados del asalto del barrio hebreo en agosto de 1391 por parte de los síndicos que estaban siendo procesados por traición desde 1388, y viceversa; mientras que en julio de 1399 el enfrentamiento de los bandos encabezados por los Centelles y los Soler, que a su vez implicaban a notabilísimos ciudadanos, habían alcanzado su punto álgido con la virulenta lucha de sus clientelas en el mismo espacio urbano 55 .

Idéntico procedimiento de activación popular y de vinculación a la lucha de facciones se observa en el dramático asalto de la morería de Valencia el 1 de junio de 1455. Otra vez, una banda de jóvenes encabezados por una banderita acosó el barrio durante la mańana con gritos en los que proclamaban «iFaçen-se cristians los moros, o muyren!».

bando Soler-Vilaragut entre 1396 y 1401: Narbona, Rafael. «L'Interregne a Valencia». En Ferrer i Mallol, M. ${ }^{a}$ Teresa (coord.). Martí l'Humà: el darrer rei de la dinastia de Barcelona (1396-1410). Barcelona: Institut d'Estudis Catalans, 2015, pp. 769-771. Sus familias estuvieron presentes en el consell de Valencia antes y después del asalto: Hug de Bordils, fue consejero de caballeros en 1399; Guillem Siscar en 1378 y 1383; Pere de Siscar en 1397 y jurado caballero en 1398; Nicolau Valldaura, padre e hijo, ocuparon consejerías por san Nicolás en 1388, 1389, 1392 y 1398, además de ejercer de jurados ciudadanos en 1389 y 1392; Guillem y Vicent Carbonell fueron consejeros ciudadanos por diferentes parroquias en 1386, 1389, 1392, 1393, 1395 y 1397; la generalización del apellido Eximénez impide identificar a quién se refería el documento, mientras que el de Carroç pertenecía a un arraigado linaje de la nobleza valenciana.

53 Según se anota, en aquel libro a.I. cap sien escrites axí singulars persones com universitats faens bons serviis e bones obres a la cosa pública, e a altre cap, los faens o tractants lo contrari, e los dits serviis e obres de cascuns, a certificació dels presents e memòria dels esdevenidors: AMV, M.C., A-19, fol. 155-156 (1390, julio 16).

54 Rubio. Epistolari, doc. 97, p. 257; y Vidal Beltrán, Eliseo. La Valencia de Juan I. València: Publicacions de la Universitat de València, 1974, pp. 60-65.

55 Noticia de los sangrientos enfrentamientos entre los Soler, los Centelles y sus respectivos partidarios: Rubio. Epistolari, doc. 120, pp. 300-306 (1399, julio 18) y doc. 121, pp. 307-310 (1399, julio 26). 
El incidente convocó a un contingente humano mucho más numeroso aquella misma tarde hasta que al anochecer los revoltosos apedrearon a la guardia creada por las autoridades para proteger el barrio mudéjar, dando pie al asalto. Días después, sobre las tres de la tarde y durante la procesión del Corpus Christi, se oyeron voces llamando a las armas a la población porque se anunció un inminente ataque de moros. El infundio se expandió de forma fulgurante y, tras comprobar su falsedad, la población se dejó arrastrar por una nueva arenga: ;Anem a casa del batle e dels oficials a robar-los, hi metam-hi foch e matem-los!. Los propios jurados, temiendo por su propia integridad, ordenaron junto al gobernador y el baile general crear doce lugartenientes del justicia criminal, con poderes expeditivos, para evitar disturbios y salvaguardar el orden público. El asalto fue imputado a una confusa masa marginal pero el proceso iniciado puso de manifiesto la implicación de algunos miembros de los linajes Cornet y Borja, además de reconocidos ciudadanos y de un importante contingente de artesanos, hasta confeccionarse una lista con un centenar de nombres que en la mayor parte de los casos acabaron silenciados con el perdón general ${ }^{56}$.

La reproducción del pogromo cumplía con los antecedentes ensayados, incluida la presencia de un agitador esgrimiendo falsas bulas papales para quien diese muerte a los moros, las cuales encontraron un eco extraordinario por el estado de animosidad general que derivaba tanto de la reciente elección de Alfonso de Borja, primer papa valenciano, como por la celebración festiva de las paces firmadas por Alfonso el Magnánimo en Italia, cuando todavía estaba vivo el fuerte impacto causado por la anterior caída de Constantinopla ante los turcos y la ansiada cruzada para conseguir su liberación. Todavía en abril de 1456 el consell comunicaba al rey el temor a una posible sedició e conmoció del poble apensadament, protagonizada por mals hòmens populars, no solo contra los moros sino también contra christians e contra los majors, per haver la roba d'aquells qui.n tenien $\mathrm{y}$, con ello, otro intento de asalto a la morería, de abierta sublevación contra la autoridad y de robo de los vecinos hacendados ${ }^{57}$. En la Navidad de 1457 aparecieron nuevos carteles en las calles exigiendo la conversión o la muerte de los musulmanes, inspirados en el falso rumor de que el rey preparaba un decreto de conversión general de los mudéjares ${ }^{58}$.

Tras los pogromos o sus amenazantes conatos, la xenofobia hacia las minorías sobrevivió, como antaño, bajo las fórmulas emocionales de desprecio y de rechazo popular, que comenzaron a redirigirse hacia los hebreos bautizados. Durante el último cuarto del siglo XV comenzó a fraguarse una explícita animadversión en Valencia hacia la integración de

56 Rubio, Agustín. Epistolari II, doc. 109, pp. 290-291; y Ruzafa García, Manuel. «FFacen-se cristians los moros o muyren!». Revista d'Història Medieval, 1990, vol. 1, pp. 87-110. Resulta especialmente significativo el protagonismo de los parientes Borja en el asalto: los hermanos Galceran, Ot y Bernardina, esposa de Galceran de Castellar, señor de Picassent, hubieron de pagar 24.000 sueldos cada uno en concepto de composición a las arcas reales. El caballero Ramon Cornet y el mercader Pere Corell, fueron ejecutados junto a un grupo de menestrales. Joan Cornet y el tintorero Pere Olesa pagaron sendos 12.000 y 2.000 sueldos para obtener el perdón; Antoni Pineda alias Mercader, Manuel de Vilanova y Carles de Vallterra, ciudadano y caballeros, se vieron implicados en el proceso junto a otros destacados personajes, cuyos servidores habían participado en el asalto.

57 Rubio. Epistolari II, doc. 111, pp. 294-295 (1456, abril 10).

58 Ruzafa Garcia, Manuel. «iFacen-se cristians los moros o muyren!», pp. 89-90. 
aquellos conversos en la sociedad civil, cuando habían gozado del manto tutelar y protector de la monarquía, del pontificado, de las órdenes religiosas, de los oficiales reales y de los mismos ediles ${ }^{59}$. En aquel momento las manifestaciones extemporáneas de desprecio, las suspicacias subyacentes y los intentos aislados e infructuosos de segregación dieron paso a un movimiento claramente político liderado por las elites descontentas.

En 1461 un tal Cervaces, barcelonés casado en Valencia, había participado en la distribución de carteles y, según se le acusaba, también estuvo presente en el asalto a la morería de 1455 . Sus vínculos con el alzamiento de los catalanes contra Juan II y su afinidad con la causa del príncipe de Viana se entrelazaban con una actitud xenófoba respecto a los conversos. En Valencia había acusado a los de Barcelona de organizar una confabulación que pretendía liberar al destituido gobernador Galceran de Requesens, el asesinato de veintisiete diputados y el control de los recursos hacendísticos de la Generalitat, todo ello argumentando el «juanismo» de los conversos y su oposición a la causa del príncipe. En consecuencia, preconizaba la necesaria muerte de los conversos conspiradores. Ante la conmoción popular desatada en Valencia entre los presuntos simpatizantes del príncipe, los conversos buscaron el amparo de la autoridad municipal, provocando la huída de Cervaces a Tortosa, mientras su mujer se quejaba públicamente de que había sido muerto bien por el gobernador o bien por los conversos valencianos ${ }^{60}$. Aquel sentimiento xenófobo siguió vivo y, de hecho, en marzo de 1470 los mudéjares de la morería de Valencia y los cristianos nuevos se quejaban ante los jurados, com havien sabut que hera parlat entre crestians moltes vegades de cór(r)e(r) la moreria e crestians novells, precisamente en el marco del revitalizado ambiente de pugna entre la oligarquía y de unas banderías con renovada participación popular ${ }^{61}$.

Pero fue en 1477 cuando comenzó a manifestarse abiertamente esa discriminación en el gobierno municipal. El 4 de junio falleció el todopoderoso Guillem Çaera, racional de Valencia durante veintiún ańos consecutivos. Con presteza y sin esperar una directriz regia el consell procedió a elegir a un sustituto mediante votación. Además, el nuevo titular quedaría privado de las atribuciones políticas que lo capacitaban para habilitar a los aspirantes en las elecciones de jurados. En aquella ocasión, Bernat Penaroja obtuvo 77 votos y Berenguer Martí de Torres, el segundo más votado, 45 sufragios. Sin embargo, Juan II nombró para el cargo a Martí de Torres, desatendiendo la elección municipal y evidenciando otra vez la disensión interna de la asamblea de gobierno, dividida en dos opciones políticas principales. Una de ellas se mostró autonomista, pues abogaba por las facultades del gobierno municipal sostenidas en los fueros y privilegios del reino, y otra de cariz regalista, aquélla que se había mantenido al frente del municipio durante el largo

59 Monsalvo Antón, José M. ${ }^{\text {« }}$ Mentalidad antijudía en la Castilla medieval. Cultura clerical y cultura popular en la gestión y difusión de un ideario medieval». Xudeus e conversos na Historia. Santiago de Compostela: La Editorial de la Historia, 1994, vol. 1, pp. 21-84; Niremberg, David. Comunidades de violencia. La persecución de minorías en la Edad Media. Barcelona: Península, 2001, pp. 284-325; Narbona Vizcaíno, Rafael. «Los conversos de Valencia». En Sabaté, Flocel y Denjean, Claude (coords.). Cristianos y judios en contacto en la Edad Media: polémica, conversión, dinero y convivencia. Lleida: Editorial Milenio, 2009, pp. 104-113.

${ }_{60}$ Rubio, Valencia, el Príncipe de Viana y Juan II, pp. 103-104; y doc. 97, pp. 225-229.

${ }^{61}$ Rodrigo, Melcior Miralles: crònica, pp. 302-303. 
mandato de Guillem Çaera ${ }^{62}$. En noviembre, en otra carta, se comunicaba al rey que tots van per València ab armes, spases en les mans e ab baynes ben trencades, per manera que la espasa va sens bayna ${ }^{63}$. La violencia de los bandos entre el patriciado volvía a aflorar. Finalmente, el consell logró que el rey nombrase al racional elegido por el municipio, y al ańo siguiente, el 6 de abril de 1478, se consiguió impugnar la ceda o lista de candidatos habilitados para optar a los escaños de jurados.

Frente a la opción del autonomismo de inspiración foral se manifestó la de un grupo bien arraigado al servicio de la monarquía. De hecho, Joan Ferragut, un perjudicado en el reparto de cargos y prebendas según el programa «autonomista» y contrario, por tanto, a la abolición de la ceda, denunció ante Juan II las irregularidades cometidas durante las recientes elecciones de jurados. Algunos aspirantes se habían presentado fuera de su circunscripción, otras parroquias carecían de candidaturas propias y, además, denunciaba que el gobierno municipal sistemáticamente expulsaba a los conversos de cualquier cargo oficial $^{64}$. Por vez primera se expresaba con toda contundencia la discriminación de los conversos. La expresión Vós sou convers, no podeu entrar en consell era atribuida por Ferragut a los jurados elegidos sin la ceda de Juan II. El 14 de julio de 1478 el rey comunicaba a los jurados que los conversos debían ser reintegrados en los cargos o, en caso contrario, los magistrados incurrirían en una pena de diez mil florines ${ }^{65}$. La orden no fue aceptada y, según parece, los jurados redoblaron su ira contra los conversos enviando una carta a su embajador en la corte, donde lo exhortaban para que obtuviera una declaración regia con la que desterrar a los cristianos nuevos de la vida pública, tildándolos de rates de farahó ${ }^{66}$. En sus inicios el denominado problema converso constituía la nueva cara con la que se presentaba la tradicional rivalidad entre las elites con objeto de desbancar a los contrarios del poder municipal.

\section{6}

CONCLUSIONES: CONFLICTO Y VIDA PÚBLICA

La heterogeneidad de las ocasiones enumeradas a lo largo de un siglo y la pluralidad de su génesis causal no impiden constatar un enfrentamiento dual en el que se observa la continua estrategia de descalificación de los contrarios. La oposición de los grupos rivales, dialéctica o violenta, constituyó una pauta de funcionamiento de la sociedad, capaz de canalizar las aspiraciones políticas de los grupos contendientes, resultando clave

Cfr. Belenguer Cebrià, Ernest. València en la crisi del segle XV. Barcelona: Edicions 62, 1976, pp.

63 Cfr. Belenguer, València, p. 137.

${ }^{64}$ Cfr. Belenguer, València, 74-75; y del mismo autor, Fernando el Católico y la ciudad de Valencia. Publicacions Universitat de València, 2012, pp. 149-150.

65 En 1478 Juan II ordenó que cessen els avalots contra els conversos i que els admeten en el seus oficis, que no tiren de la cancilleria els sindics nomenats aixi, i que se'ls tracte amb els mateixos honors, oficis $i$ beneficis, segons la condició de cada u, sense cap discrepància dels altres, altrament seria ofensa de nostre Senyor Déu: Garcia, Angelina. Els Vives, una família de jueus valencians. València: Eliseu Climent editor, 1987, p. 80. También Belenguer, València, p. 78.

${ }_{66}$ Rubio, Epistolari II, doc. 134, pp. 338-339 (1478, julio 30). 
a la hora de tejer relaciones sociales complejas. El uso de rumores, gritos o arengas, la circulación de libelos o panfletos, y la plasmación de epitafios y rótulos murales, cuando no abiertas algaradas — que en ocasiones acabaron en auténticos pogromos- fueron recursos empleados de forma continua como estrategia política en un medio urbano con un grado de alfabetización y de politización más que suficiente, que se inscribe en la reiterada lucha por ejercer, mantener o conseguir, el poder local.

El recurrente uso de carteles con textos breves — albarans, bitllets o libels - siempre murales, o la reiteración de gritos y lemas, significaron la continuación de una disidencia y la contestación a las políticas gubernativas en un intento de hacerse visible en la mejor escena con el mayor impacto comunicativo. La situación de perenne tensión facilitaba las protestas para descalificar a los gobernantes y a sus actuaciones. Las voces anónimas y los escritos clandestinos, escuchados y expuestos públicamente en esquinas y plazas, ejemplificaban la premeditación y la función propagandística de esos breves discursos o sencillos rótulos. Su finalidad era doble, desacreditar a los titulares del poder en su honorabilidad personal y pública al mismo tiempo que desautorizar su papel y su eficacia gubernativa - considerada interesada y parcial — ante el conjunto de la comunidad.

Estas acciones fugaces aspiraban a conseguir gran calado social y su breve vida útil contrastaba con el gran potencial publicitario de los textos entre los posibles lectores, que debemos considerar verdaderos altavoces entre los vecindarios analfabetos. Con este matiz se entiende que no se excluyese el recurso a las más graves y malintencionadas acusaciones para atentar contra la reputación de los próceres que desempeñaban las magistraturas, dada la indisociable convivencia comunitaria de la infamia y del honor. El anonimato constituyó pues un elemento fundamental e imprescindible de expresión de la disidencia, completamente asociado a la nocturnidad en la distribución y colocación de pasquines por los lugares más emblemáticos. Difundidos sin autor y sin testigos, preservaban la impunidad de los actores y, al mismo tiempo, encontrar gran resonancia. Un ejercicio arriesgado que pretendía sustituir la voz solemne y ceremonial de los pregones y de las ordenanzas por los corrillos y las murmuraciones. Esa subversiva usurpación del espacio público con mensajes contestatarios, elaborados sobre papel y pegados a los muros con engrudo, constituyeron una continua transgresión del orden. En ocasiones los acuerdos municipales parecen referirse a mensajes más explícitos, incluso a libelos acusatorios, que engendraban la indignación de los aludidos y la posible simpatía de algunos vecinos complacidos. Sin duda los mensajes no excluían las chanzas vacuas o las más terribles amenazas, pero también exigían un tiempo preliminar de reflexión para concebir los escritos cuando no la redacción en coplas, cantinelas o lemas de fácil comprensión. No disponemos de los textos ni de las frases difamatorias empleadas, pero teniendo constancia del grave impacto causado entre las autoridades, hemos de deducir ciertos usos burlescos en lengua vulgar, capaces de acentuar la crítica que tanto desagradaba y escandalizaba a los próceres urbanos. Aquellos incidentes desencadenaban un punto específico en el orden del día en la inmediata reunión de la asamblea municipal, e incluso obligaban a pregonar con trompeta y tambor las amenazas contra los infractores que atentaban contra la res publica. La previsión de sanciones capitales, muerte y confiscación de bienes, y su aplicación especialmente prevista para gentes laborales y de modesta condición significan 
bien que el disentimiento o las luchas urbanas no fueron monopolio de las elites en las sociedades dotadas de un fuerte componente comunitario. Estas voces incontroladas de origen incierto constatan un rechazo a la autoridad por parte de quienes no la ejercían y nos remite a los enemigos del grupo en el poder y a aquellos que carecían de voz o de fuerza en el foro municipal.

Con los ejemplos aducidos, se comprende que el uso de estos mensajes contestatarios, de este lenguaje y su distribución clandestina, ratificaba la vitalidad de las rivalidades de grupo, la insumisión al grupo hegemónico y la perennidad de los descontentos. Su objetivo no fue otro que movilizar la oposición a través de unos discursos —al menos en negativo- que reaccionaban contra el quehacer institucional y, al mismo tiempo, expresaban la voluntad de recambio del grupo dirigente. Los gritos y los carteles, las palabras y los escritos, se lanzaban contra los considerados tiránicos administradores, chispas que encendiesen la conjura a la espera de activar una respuesta colectiva y airada de una parte de la población. En consecuencia, la reacción del poder era inmediata y desataba un mayor control social para evitar la confabulación, mediante una actuación más administrativa que ideológica al identificarse orden público con eficacia de la acción de gobierno, que precisamente era entonces denostada. Podemos considerar pues que estas acciones subversivas y de difamación de los próceres conjugaban la persuasión y la venganza en una estrategia continuada para ganar las emociones y los sentimientos de la población. Es más, esta continua disidencia subrayaba la perseverancia de un activismo político extrainstitucional, al margen de un senado municipal domesticado como órgano de discusión y de reivindicación.

\section{REFERENCIAS BIBLIOGRÁFICAS}

Asenjo, María y Zorzi, Andrea. "Conflicto y discordia en las ciudades bajomedievales. Italia y reinos hispánicos». Hispania, 2015, vol. LXXV, n. ${ }^{\circ}$ 250, pp. 323-330.

Barceló Crespí, María (coord.). Estudis Baleàrics, 1988, vol. 31.

Barel, Yves. La ciudad medieval. Sistema social-sistema urbano. Madrid: Instituto de Estudios de la Administración Local, 1981.

Barrio Barrio, Juan Antonio. «La organización municipal en Alicante. Siglos XIV-XV». Historia Medieval. Anales de la Universidad de Alicante, 1988-89, vol. 7, pp. 137-158.

Barrio Barrio, Juan Antonio. Gobierno municipal de Oribuela durante el reinado de Alfonso $V$ (1416-1458). Alacant: Universitat de Alacant, 1995.

Batlle i Gallart, Carme et al. El Llibre de Consell de la ciutat de Barcelona. Segle XIV: les eleccions municipals. Barcelona: Institució Milà i Fontanals, 2007.

Belenguer Cebrià, Ernest. Fernando el Católico y la ciudad de Valencia. València: Publicacions Universitat de València, 2012.

Belenguer Cebrià, Ernest. València en la crisi del segle XV. Barcelona: Edicions 62, 1976.

Bernabeu Borja, Sandra. La ciutat i el rei. Govern, societat i elits valencianes. Tesis doctoral. Valencia: Universitat de València, 2017.

Bertelli, Sergio. Il potere oligarchico nello stato-città medievale. Florencia: La Nuova Italia Editrize, 1978. 
Bouza, Fernando. Corre manuscrito. Una historia cultural del Siglo de Oro. Madrid: Marcial Pons, 2001.

Castillo Gómez, Antonio. Entre la pluma y la pared. Una historia social de la escritura en los Siglos de Oro. Madrid: Akal, 2006.

Cateura Bennàsser, Pau. «El bipartidismo en Mallorca a comienzos del siglo xv». Boletín de la Sociedad Arqueológica Luliana, 1985, vol. 41, pp. 157-170.

Escartí, Vicent Josep y Borràs, Marc Jesús. «Albarans de commoure a la València del segle Xv. Sobre els usos públics i criminals de l'escriptura». En Ferrando, Antoni y Hauf, Albert (eds.). Miscel.lània Joan Fuster. Estudis de Llengua i Literatura IV. Barcelona: Abadía de Montserrat, 1991, pp. 75-96.

Evangelisti, Paolo. I franciscani e la costruzioni di uno Stato. Linguaggi politici, valori identitari, progetti di governo in area catalo-aragonese. Padua: Editrici Franciscane, 2006.

Garcia, Angelina. Els Vives, una família de jueus valencians. València: Eliseu Climent editor, 1987.

Gimeno, Francisco y Escartí, Vicent Josep. «El testimonio cronístico del uso de la escritura popular-escritura criminal en la Valencia del siglo Xviı". Alfabetismo y Cultura Escrita, 1988, vol. 1, pp. 23-28.

Gimeno, Francisco. «Défense d'afficher: cuando escribir es transgredir». En Gimeno, Francisco y Mandingorra, M. ${ }^{a}$ Luz (coords.). Los muros tienen la palabra: materiales para la historia de los graffiti. Valencia: Universidad de Valencia, 1997, pp. 11-26.

Guilleré, Christian. Girona al segle XIV. Barcelona: Publicaciones de l'Abadia de Montserrat, 1993, vol. 2.

Heers, Jacques. Partiti e vita politica nell'Occidente medievale. Milán: Arnolfo Mondadori editore, 1983.

Heers, Jaques. L'esilio, la vita política e la società nel Medioevo. Nápoles: Liguore editore, 1997.

Iradiel, Paulino, Navarro, Germán, Igual, David y Villanueva, Concepción (eds.). Identidades urbanas: Corona de Aragón-Italia. Redes económicas, estructuras institucionales, funciones políticas (siglos XIV-XV). Zaragoza: Prensas de la Universidad de Zaragoza, 2016.

Juncosa Bonet, Eduard. «Muyren los traydors! La lucha de bandos en Tarragona a fines del siglo XIV». Hispania, 2015, vol. LXXV, n. ${ }^{\circ} 250$, pp. 441-466.

Lantschner, Patrick. The Logic of Political Conflict in Medieval Cities: Italy and the Southern Low Countries, 1370-1440. Oxford: Oxford University Press, 2015.

Llop Català, Miguel. «Proceso a Bonifacio Ferrer». Escritos del Vedat, 1980, vol. 10, pp. 415-471.

Maravall, José Antonio. «Franciscanismo, burguesía y mentalidad precapitalista: la obra de Eiximenis». En VIII Congreso de Historia de la Corona de Aragón. Valencia: Sucesor de Vives Mora, I969, pp. 285-306.

Molins de Rei, Daniel (ed.). Regiment de la cosa pública. Barcelona: Barcino, 1927.

Monsalvo Antón, José M. ${ }^{a}$ «El conflicto nobleza frente a monarquía en el contexto de las transformaciones del estado en la Castilla Trastámara. Reflexiones críticas». En Jara Fuente, José Antonio (coord.). Discurso politico y relaciones de poder: ciudad, nobleza y monarquía en la Baja Edad Media. Madrid: Dykinson, 2017, pp. 89-287.

Monsalvo Antón, José M. ${ }^{a}$ "Mentalidad antijudía en la Castilla medieval. Cultura clerical y cultura popular en la gestión y difusión de un ideario medieval». Xudeus e conversos na Historia. Santiago de Compostela: La Editorial de la Historia, 1994, vol. 1, pp. 21-84.

Muñoz Pomer, Rosa. «Las Cortes a través de la ciudad: Valencia en las Cortes de don Martín». Saitabi, 2001-2002, vol. 51-52, pp. 137-159.

Narbona Vizcaíno, Rafael. "Alfonso el Magnánimo, Valencia y el oficio de racional». En D’Agostino, Guido y Buffardi, Giulia (eds.). XVI Congresso Internazionale di Storia de la 
Corona d'Aragona. Celebrazioni Alfonsine. Nápoles: Comune di Napoli-Paparo Edizioni, 2000, vol. I, pp. 593-617.

Narbona Vizcaíno, Rafael. «Algunas reflexiones sobre la participación vecinal en las ciudades de la Corona de Aragón (ss. XII-Xv)». Res Publica: revista de filosofía política, 2007, vol. 7, pp. 113-150.

Narbona Vizcaíno, Rafael. «Bandos populares en la Valencia del Trescientos. Obligaciones de reciprocidad, socorro y consejo en la sociabilidad urbana». En Monsalvo, José M. a (ed.). Élites, conflictos y discursos politicos en las ciudades bajomedievales de la peninsula Ibérica. Salamanca: Ediciones Universidad de Salamanca, 2019, pp. 271-296.

Narbona Vizcaíno, Rafael. «El trienio negro: Valencia, 1389-1391. Turbulencias coetáneas al asalto de la judería». En la España Medieval, 2012, vol. 35, pp. 177-210.

Narbona Vizcaíno, Rafael. «L'Interregne a Valencia». En Ferrer i Mallol, M. ${ }^{a}$ Teresa (coord.). Martí l'Humà: el darrer rei de la dinastia de Barcelona (1396-1410). Barcelona: Institut d'Estudis Catalans, 2015, pp. 767-789.

Narbona Vizcaíno, Rafael. "La idiosincrasia de las sociedades urbanas en la Corona de Aragón. Ideales, realidades políticas y representación social (siglos XIII-XV)». En El poder a l'Edat Mitjana. Lleida: Pagès Editor, 2004, pp. 293-322.

Narbona Vizcaíno, Rafael. «Los conversos de Valencia». En Sabaté, Flocel y Denjean, Claude (coords.). Cristianos y judios en contacto en la Edad Media: polémica, conversión, dinero y convivencia. Lleida: Editorial Milenio, 2009, pp. 101-146.

Narbona Vizcaíno, Rafael. «Política i ciutadania a la València de sant Vicent Ferrer». Afers. Fulls de recerca i pensament, 2018, vol. 33, n. ${ }^{\circ}$ 90-91, pp. 425-450.

Narbona Vizcaíno, Rafael. «Ruzafa, una comunidad rural convulsa (1395-1403)». En Del Val, M. ${ }^{a}$ Isabel, Martín Cea, Juan Carlos, y Carvajal, David (eds.). Expresiones del poder en la Edad Media. Homenaje al profesor Juan Antonio Bonachia Hernando. Valladolid: Ediciones Universidad de Valladolid, 2019, pp. 421-430.

Narbona Vizcaíno, Rafael. Valencia municipio medieval. Poder politico y luchas ciudadanas (12381418). Valencia: Ayuntamiento de Valencia, 1995.

Niremberg, David. Comunidades de violencia. La persecución de minorias en la Edad Media. Barcelona: Península, 2001.

Oliva Ferrer, Hipólito Rafael. «Espacios de comunicación en el mundo rural a fines de la Edad Media: la escritura como contrapeso del poder». Medievalismo, 2006, vol. 16, pp. 93-112.

Oliva Ferrer, Hipólito Rafael. «Sobre la politización ordinaria de la gente común a fines de la Edad Media». En López Ojeda, Esther (coord.). Una nueva visión de la Edad Media: legado y renovación. XXV Semana de Estudios Medievales. Logrońo: Instituto de Estudios Riojanos, 2016, pp. 259-290.

Oliva Herrer, Hipólito Rafael et al. (eds.). La comunidad medieval como esfera pública. Sevilla: Universidad de Sevilla, 2014.

Petralia, Giuseppe. «Conclusioni». En Balbi, Giovanna Petti y Vitolo, Giovanni. Linguaggi e pratiche del potere. Genova e il Regno de Napoli tra Medioevo ed Età moderna. Salerno: Laveglia editore, 2007.

Petrucci, Armando. Scrittura e popolo nella Roma barroca, 1585-1721. Roma: Edizioni QuasarComunes di Roma, 1982.

Renedo, Xavier. "Introducció» del Dotzè llibre del Crestià, I, 1. Girona: Universitat de Girona, 2005.

Ryder, Alan. Alfonso el Magnánimo, rey de Aragón, Nápoles y Sicilia. València: Alfons el Magnànim, 1992. 
Rodrigo Lizondo, Mateu (ed.). Melcior Miralles: crònica i dietari del capellà d'Alfons el Magnànim. València: Publicacions Universitat de València, 2011.

Rubio Vela, Agustín. «Después de Caspe. El urgelismo y las oligarquías». En Sesma Muñoz, José Ángel (coord.). La Corona de Aragón en el centro de su historia, 1208-1458. El Interregno y el Compromiso de Caspe. Zaragoza: Gobierno de Aragón-Grupo de Investigación C.E.M.A., 2012, pp. 265-292.

Rubio Vela, Agustín. «El justicia de Aragón frente a la ciudad de Valencia. Un conflicto entre oligarquías territoriales, 1395-1404». Aragón en la Edad Media, 2014, vol. 25, pp. 273-322.

Rubio Vela, Agustín. «Urgelistas valencianos. Sobre la oposición a Fernando I de Trastámara». Anuario de Estudios Medievales, 2003, vol. 33, n.o 1, pp. 191-261.

Rubio Vela, Agustín. Epistolari de la València medieval II. Barcelona-València: Institut Interuniversitari de Filologia Catalana-Abadía de Montserrat, 1998.

Rubio Vela, Agustín. Epistolari de la València medieval. València-Barcelona: Institut de Filologia Valenciana, 1985.

Rubio Vela, Agustín. Valencia, el Principe de Viana y Juan II. Un patriciado ante la crisis politica de la monarquía (1460-1461). Valencia: Gráficas Papallona, 2016.

Ruzafa García, Manuel. "iFacen-se cristians los moros o muyren!». Revista d'Història Medieval, 1990, vol. 1, pp. 87-110.

Santamaría Arandez, Álvaro. «Los consells municipales de la Corona de Aragón mediado el siglo XIII: el sistema de cooptación». Anuario de Historia del Derecho Español, 1981, vol. 51, pp. 291-364.

Santamaría Arandez, Álvaro. El Consell de Valencia en el tránsito a la modernidad. Valencia: Generalitat Valenciana, 2000.

Terol, Vicent. «Escriptures infamants valencianes. A propósit d'un cartell del segle xviI»». En Gimeno, Francisco y Mandingorra, M. ${ }^{a}$ Luz (coords.). Los muros tienen la palabra: materiales para la historia de los graffiti. Valencia: Universidad de Valencia, 1997, pp. 149-162.

Viciano Navarro, Pau. Regir la Cosa Pública. Prohoms i poder local a la vila de Castelló (segles XIV-XV). València: Publicacions Universitat de València, 2008.

Vidal Beltrán, Eliseo. La Valencia de Juan I. València: Publicacions de la Universitat de València, 1974.

Webster, Jill. La societat catalana al segle XIV. Barcelona: Edicions 62, 1980. 